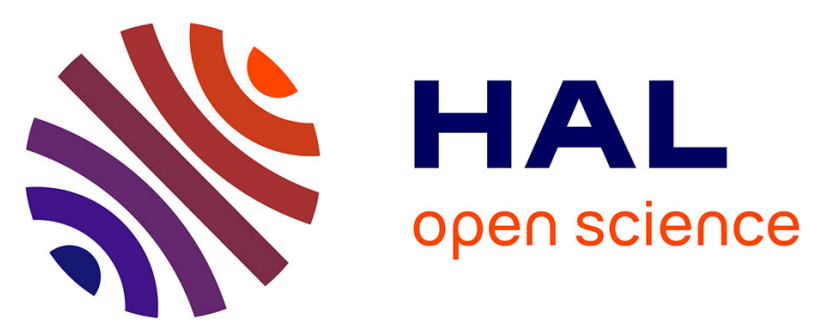

\title{
Influence of the Preparation Procedure of Vanadium-Containing SiBEA Zeolites on Their Catalytic Activity in Propene Epoxidation
}

Agnieszka Held, Jolanta Kowalska-Kuś, Yannick Millot, Frederic Averseng, Christophe Calers, Laetitia Valentin, Stanislaw Dzwigaj

\section{To cite this version:}

Agnieszka Held, Jolanta Kowalska-Kuś, Yannick Millot, Frederic Averseng, Christophe Calers, et al.. Influence of the Preparation Procedure of Vanadium-Containing SiBEA Zeolites on Their Catalytic Activity in Propene Epoxidation. Journal of Physical Chemistry C, 2018, 122 (32), pp.18570-18582. 10.1021/acs.jpcc.8b05731 . hal-01909346

\section{HAL Id: hal-01909346 \\ https: / hal.sorbonne-universite.fr/hal-01909346}

Submitted on 31 Oct 2018

HAL is a multi-disciplinary open access archive for the deposit and dissemination of scientific research documents, whether they are published or not. The documents may come from teaching and research institutions in France or abroad, or from public or private research centers.
L'archive ouverte pluridisciplinaire HAL, est destinée au dépôt et à la diffusion de documents scientifiques de niveau recherche, publiés ou non, émanant des établissements d'enseignement et de recherche français ou étrangers, des laboratoires publics ou privés. 


\title{
Influence of the Preparation Procedure of Vanadium-Containing SiBEA Zeolites on Their Catalytic Activity in Propene Epoxidation
}

Agnieszka Held, ${ }^{*}+\oplus$ Jolanta Kowalska-Kus, ${ }^{\dagger}$ Yannick Millot, ${ }^{\ddagger}$ Frederic Averseng, ${ }^{\ddagger}$ Christophe Calers, ${ }^{\ddagger}$ Laetitia Valentin, and Stanislaw Dzwigaj,

${ }^{\dagger}$ Faculty of Chemistry, Adam Mickiewicz University, 61-614 Poznan, Poland

${ }^{\ddagger}$ Laboratoire de Réactivité de Surface, Sorbonne Université-CNRS, UMR 7197, F-75005 Paris, France

Supporting Information

\begin{abstract}
Two series of V-containing BEA zeolite catalysts, $\mathrm{V}_{x} \mathrm{SiBEA}(\mathrm{I})$ and $\mathrm{V}_{x} \operatorname{SiBEA}(\mathrm{II})$, were prepared by a two-step postsynthesis preparation procedure which consists, in the first step, in the dealumination of TEABEA zeolites by a treatment with nitric acid solution to obtain SiBEA zeolites with a $\mathrm{Si} / \mathrm{Al}$ atomic ratio of 1000 and then, in the second step, in bringing SiBEA into contact with an aqueous $\mathrm{NH}_{4} \mathrm{VO}_{3}$ solution with different concentrations at a $\mathrm{pH}$ of 2.7. After 3 days, the solids were recuperated from the reaction mixtures: (1) on a sinter funnel and washed several times with distilled water to obtain the $\mathrm{V}_{x} \mathrm{SiBEA}(\mathrm{I})$ series and (2) in a rotating evaporator under vacuum via a membrane pump to obtain the

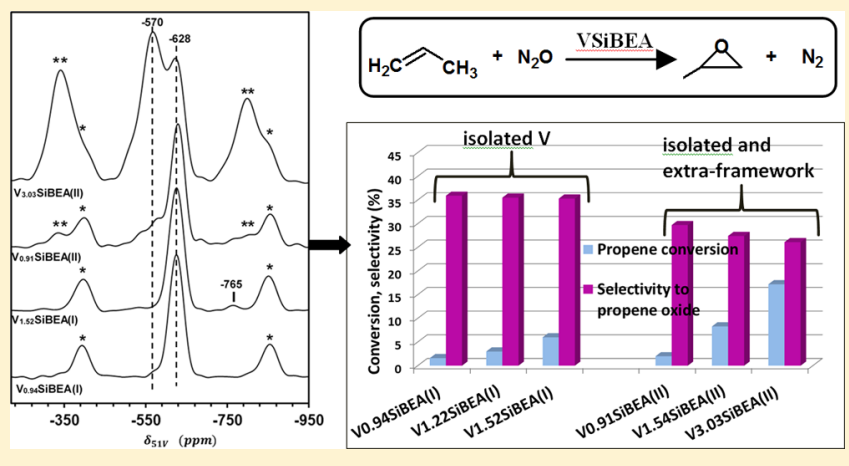
$\mathrm{V}_{x} \mathrm{SiBEA}(\mathrm{II})$ series. The combined use of $\mathrm{H}_{2}$-temperatureprogrammed reduction, diffuse reflectance (DR) UV-vis, Fourier transform infrared (FTIR), ${ }^{51} \mathrm{~V}$ magic-angle spinning (MAS) $\mathrm{NMR}$, electron paramagnetic resonance (EPR), and X-ray photoelectron spectroscopy allows determining the nature and environment of vanadium in both series of $\mathrm{V}$-containing SiBEA zeolites after different treatments. The characterization of $\mathrm{V}_{x} \mathrm{SiBEA}(\mathrm{I})$ and $\mathrm{V}_{x} \mathrm{SiBEA}(\mathrm{II})$ series reveals the formation of various forms of vanadium species depending on the $\mathrm{V}$ content and conditions applied upon preparation of each series of V-containing SiBEA zeolites. As evidenced by DR UV-vis and ${ }^{51} \mathrm{~V}$ MAS NMR in the $\mathrm{V}_{x} \mathrm{SiBEA}(\mathrm{I})$ series, vanadium was present mainly as mononuclear framework pseudo-tetrahedral $\mathrm{V}(\mathrm{V})$ species. In contrast, in the $\mathrm{V}_{x} \mathrm{SiBEA}(\mathrm{II})$ series, vanadium was present as mononuclear framework pseudo-tetrahedral and polynuclear extraframework pseudo-octahedral V(V) species. As shown by EPR, the oxidation state of V species easily changes upon calcinations in oxygen, outgassing under vacuum at $773 \mathrm{~K}$ and treatment with hydrogen at a high temperature (873 K). The presence of Brønsted and Lewis acidic centers was evidenced in both $\mathrm{V}_{x} \operatorname{SiBEA}(\mathrm{I})$ and $\mathrm{V}_{x} \mathrm{SiBEA}(\mathrm{II})$ series by FTIR spectroscopy with pyridine used as a probe molecule. The catalytic activity tests in propene epoxidation revealed that the highly dispersed mononuclear framework pseudo-tetrahedral $V(V)$ species are responsible for high selectivity to propene oxide, whereas polynuclear extra-framework pseudo-octahedral $\mathrm{V}(\mathrm{V})$ species catalyzed mainly total oxidation. The $\mathrm{V}_{x} \mathrm{SiBEA}(\mathrm{I})$ series of catalysts with vanadium, present mainly as mononuclear framework pseudo-tetrahedral $\mathrm{V}(\mathrm{V})$ species, show lower turn over frequency values than the $\mathrm{V}_{x} \mathrm{SiBEA}(\mathrm{II})$ series in which vanadium is present as both mononuclear framework pseudotetrahedral $\mathrm{V}(\mathrm{V})$ species and polynuclear extra-framework pseudo-octahedral $\mathrm{V}(\mathrm{V})$. It thus demonstrates that apart from highly dispersed isolated vanadium species, the availability of vanadium species to reagents also plays an important role in the gas-phase propene epoxidation.
\end{abstract}

\section{INTRODUCTION}

Vanadium oxide supported on different supports has been shown to be an active catalyst for many oxidation reactions. ${ }^{1}$ It has been evidenced that the activity of vanadium catalysts depends significantly on the nature of the employed support, the vanadium content, and their modification. ${ }^{2,3}$ These parameters influence the vanadium species structure, acidity of the catalysts as well as availability of the active sites to reagents. Considering this, a number of inorganic oxides, such as silica, alumina, titania, and magnesia, as well as some zeolites and mesoporous materials have been used as vanadia supports. $^{4,5}$
Recently, it has been found that vanadium-modified silica matrices (amorphous $\mathrm{SiO}_{2}, \mathrm{SBA}-3, \mathrm{SBA}-15$, and MCM-41) showed noticeable activity for propene epoxidation with $\mathrm{N}_{2} \mathrm{O}$ as an oxidant. $^{6}$ It was pointed out that isolated vanadium species could be responsible for the high selectivity toward propene oxide (PO), whereas oligomeric vanadium species or bulk vanadia could induce $\mathrm{PO}$ isomerization and total oxidation reactions. ${ }^{7}$ The above-mentioned vanadium catalysts 
were prepared by means of an impregnation method leading to the presence of various vanadium species: isolated, oligomeric, and even some amount of bulk vanadia at high $\mathrm{V}$ loadings.

Depending on the method of vanadium introduction, different kinds of vanadium species could be generated in the final catalysts. One of the most widely studied vanadiumcontaining catalytic systems is the vanadium-modified BEA $(\beta)$ zeolite. ${ }^{8,9}$ Such a catalytic system could be obtained by a classical impregnation or a two-step postsynthesis method developed earlier by Dzwigaj et al., ${ }^{9}$ using an aqueous solution of $\mathrm{NH}_{4} \mathrm{VO}_{3}$ as the vanadium precursor. The latter preparation method consisted of removal of aluminum ions from the framework of the BEA zeolite by treatment with nitric acid, in the first step, and then, in the second step, incorporation of vanadium ions into the framework of the dealuminated BEA zeolite (SiBEA) to obtain V-containing SiBEA zeolites $\left(\mathrm{V}_{x} \mathrm{SiBEA}\right)$. It was found that dealuminated zeolite $\beta$ constitutes one of the most interesting matrices for such lattice vanadium implementation. A controlled dealumination procedure performed by means of the partial removal of aluminum leads to the formation of vacant $\mathrm{T}$-atom sites. The subsequent contact with aqueous solution of $\mathrm{NH}_{4} \mathrm{VO}_{3}$ at low $\mathrm{pH}$ brings about the incorporation of tetrahedrally coordinated vanadium ions into the zeolite framework. ${ }^{8}$ This technique allows preparation of highly isolated vanadium (V) species in pseudo-tetrahedral coordination. Such pseudo-tetrahedral vanadium species have been suggested as active centers of propane and ethane oxidation, oxidative dehydrogenation, ${ }^{10,11}$ and propane ammoxidation. ${ }^{12}$

In this paper, we report on the effect of the conditions of the preparation procedure on the state of vanadium ions (oxidation state, coordination number, and nature) and its effect on catalytic activity in propene epoxidation. Taking into account the above findings, the dealuminated BEA zeolite (SiBEA) has been modified with vanadium incorporated into a T-atom vacancy and also using a simple impregnation method. The influence of the nature of vanadium species on the catalytic performance of the VSiBEA materials is discussed on the basis of detailed characterization of the physicochemical properties of the catalysts by low-temperature $\mathrm{N}_{2}$ adsorption/ desorption isotherms, X-ray photoelectron spectroscopy (XPS,) NMR, $\mathrm{H}_{2}$-temperature-programmed reduction (TPR) measurements, electron paramagnetic resonance (EPR), diffuse reflectance (DR) UV-vis spectra, and Fourier transform infrared (FTIR) bands of adsorbed pyridine.

\section{EXPERIMENTAL SECTION}

2.1. Material Preparation. A tetraethylammonium BEA (TEABEA) zeolite with a $\mathrm{Si} / \mathrm{Al}$ atomic ratio of 17 was separated into two fractions. The first fraction of TEABEA was calcined in air at $823 \mathrm{~K}$ for $15 \mathrm{~h}$ under static conditions to remove the organic template. The obtained organic-free zeolite was labeled HAIBEA. The second fraction of TEABEA was dealuminated by a treatment with nitric acid solution $(13 \mathrm{~mol}$ $\mathrm{L}^{-1}$ ) at $353 \mathrm{~K}$ for $4.5 \mathrm{~h}$ to obtain the dealuminated BEA with a $\mathrm{Si} / \mathrm{Al}$ atomic ratio of 1000 and was labeled SiBEA. After that, the SiBEA sample was washed several times with distilled water and dried at $368 \mathrm{~K}$ overnight. It was then brought into contact with an aqueous $\mathrm{NH}_{4} \mathrm{VO}_{3}$ solution in excess $(2 \mathrm{~g}$ of zeolite in $50 \mathrm{~mL}$ of solution with different concentrations of $\mathrm{NH}_{4} \mathrm{VO}_{3}$ varied from 0.6 to $2.6 \times 10^{-3} \mathrm{~mol} \mathrm{~L}^{-1}$ ) at $\mathrm{pH}=2.7$. At such concentration around $10^{-3} \mathrm{~mol} \mathrm{~L}^{-1}$ and $\mathrm{pH}$ of 2.7 , the aqueous $\mathrm{NH}_{4} \mathrm{VO}_{3}$ solution is known to contain mononuclear $\mathrm{VO}_{2}^{+}$ ions. ${ }^{13}$ The suspensions obtained were left standing for 3 days at room temperature, and then, the suspensions were separated into two fractions:

(i) The separation of the solids from the first fraction of suspensions was carried out on a sinter funnel. Then, the solids were washed several times with distilled water and dried at $368 \mathrm{~K}$ overnight. The obtained solids containing $0.94,1.22$, and $1.52 \mathrm{~V}$ wt $\%$ were labeled as $\mathrm{V}_{0.94} \operatorname{SiBEA}(\mathrm{I}), \mathrm{V}_{1.22} \operatorname{SiBEA}(\mathrm{I})$, and $\mathrm{V}_{1.52} \operatorname{SiBEA}(\mathrm{I})$.

(ii) The separation of the solids from the second fraction of suspensions was done in an evaporator under vacuum of a membrane pump for $2 \mathrm{~h}$ in air at $333 \mathrm{~K}$. The obtained solids containing $0.91,1.54$, and $3.03 \mathrm{~V}$ wt $\%$ were labeled as $\mathrm{V}_{0.91} \operatorname{SiBEA}(\mathrm{II}), \mathrm{V}_{1.54} \operatorname{SiBEA}(\mathrm{II})$, and $\mathrm{V}_{3.03} \operatorname{SiBEA}(\mathrm{II})$.

The $\mathrm{V}_{0.94} \operatorname{SiBEA}(\mathrm{I}), \mathrm{V}_{1.22} \operatorname{SiBEA}(\mathrm{I}), \mathrm{V}_{1.52} \operatorname{SiBEA}(\mathrm{I})$, and $\mathrm{V}_{0.91} \mathrm{SiBEA}(\mathrm{II})$ samples were white, suggesting the presence of only tetrahedral $\mathrm{V}(\mathrm{V})$ species, in line with our earlier work. ${ }^{8}$ In contrast, the $\mathrm{V}_{1.54} \mathrm{SiBEA}(\mathrm{II})$ and $\mathrm{V}_{3.03} \mathrm{SiBEA}(\mathrm{II})$ samples were pale yellow, suggesting the presence of not only tetrahedral but also octahedral $\mathrm{V}(\mathrm{V})$ species, either as mononuclear and/or polynuclear $\mathrm{V}(\mathrm{V})$ species, in line with our earlier report. ${ }^{8}$

2.2. Material Characterization. An inductively coupled plasma optical emission (ICP-OES Quantima Sequential) spectrometer from $\mathrm{GBC}$ was used to estimate the vanadium loading in the catalysts.

The specific surface area and the volume of micropores were measured by the $\mathrm{N}_{2}$ adsorption-desorption method using a NOVA 1000e (Quantachrome) instrument. The samples were activated at $573 \mathrm{~K}$ for $16 \mathrm{~h}$ under vacuum and then the adsorption/desorption was conducted by passing nitrogen into the sample, which was kept at liquid nitrogen temperature. The specific surface area was determined from the linear portion of the Brunauer-Emmett-Teller (BET) plot. The volume of micropores was evaluated by the $t$-plot method.

Analysis of the acidic properties of the samples was performed by adsorption of pyridine (Py) followed by infrared spectroscopy. Before analysis, the samples were pressed at $\sim 1$ ton $\mathrm{cm}^{-2}$ into thin wafers of ca. $10 \mathrm{mg} \mathrm{cm}^{-2}$ and placed inside the IR cell.

Before Py adsorption/desorption experiments, the wafers were activated by calcination under static conditions at $723 \mathrm{~K}$ for $3 \mathrm{~h}$ in $\mathrm{O}_{2}\left(1.6 \times 10^{4} \mathrm{~Pa}\right)$ and then outgassed under secondary vacuum at $573 \mathrm{~K}\left(10^{-3} \mathrm{~Pa}\right)$ for $1 \mathrm{~h}$. These wafers were brought into contact at room temperature with gaseous Py $(133 \mathrm{~Pa})$ via a separate cell containing liquid Py. The spectra were then recorded following desorption at room temperature and $423 \mathrm{~K}$ for $1 \mathrm{~h}$ with a Bruker Vector 22 spectrometer (resolution $2 \mathrm{~cm}^{-1}, 128$ scans). The reported spectra were obtained after subtraction of the spectrum recorded before Py adsorption.

Temperature-programmed reductions (TPR) were carried out in a homemade setup equipped with a thermal conductivity detector (TCD). Each sample of ca. $100 \mathrm{mg}$ was introduced into a quartz tubular reactor. Before the experiment, the sample was pretreated in helium at $673 \mathrm{~K}$ for $60 \mathrm{~min}$ to remove adsorbed water. $\mathrm{H}_{2}$-TPR experiments were performed under a flow of 10 vol $\% \mathrm{H}_{2} / \mathrm{Ar}\left(70 \mathrm{~cm}^{3} \mathrm{~min}^{-1}\right)$ from 373 to $1173 \mathrm{~K}$ at a constant heating rate $\left(10 \mathrm{~K} \mathrm{~min}^{-1}\right)$.

EPR spectra were recorded on a JEOL FA-300 series EPR spectrometer operating at $\approx 9.3 \mathrm{GHz}$ (X band) using a 100 
Table 1. Chemical Analysis, Si/Al Ratio, Specific Surface Areas, Micropores Volumes, Diameters, and V Surface Density of SiBEA, $V_{0.94} \operatorname{SiBEA}(\mathrm{I}), \mathrm{V}_{1.22} \operatorname{SiBEA}(\mathrm{I}), \mathrm{V}_{1.52} \operatorname{SiBEA}(\mathrm{I}), \mathrm{V}_{0.91} \operatorname{SiBEA}(\mathrm{II}), \mathrm{V}_{1.54} \operatorname{SiBEA}(\mathrm{II})$, and $\mathrm{V}_{3.03} \operatorname{SiBEA}(\mathrm{II})$

\begin{tabular}{llllccc}
\multicolumn{1}{c}{ catalyst } & $\mathrm{V} \%^{a}$ & $\mathrm{Al} \%^{a}$ & $\mathrm{Si} / \mathrm{Al}$ & $S_{\text {BET }}\left(\mathrm{m}^{2} \mathrm{~g}^{-1}\right)$ & $V_{\text {mic }}\left(\mathrm{cm}^{3} \mathrm{~g}^{-1}\right)^{b}$ & surface density $\left(\mathrm{V}\right.$ atoms nm $\left.{ }^{-2}\right)$ \\
SiBEA & & & & 512 & 0.20 & 0.24 \\
$\mathrm{~V}_{0.94} \mathrm{SiBEA}(\mathrm{I})$ & 0.94 & 0.11 & 864 & 456 & 0.20 & 0.34 \\
$\mathrm{~V}_{1.22} \mathrm{SiBEA}(\mathrm{I})$ & 1.22 & 0.11 & 862 & 423 & 0.19 & 0.43 \\
$\mathrm{~V}_{1.52} \mathrm{SiBEA}(\mathrm{I})$ & 1.52 & 0.09 & 1050 & 414 & 0.18 & 0.24 \\
$\mathrm{~V}_{0.91} \mathrm{SiBEA}(\mathrm{II})$ & 0.91 & 0.09 & 1057 & 453 & 0.18 & 0.41 \\
$\mathrm{~V}_{1.54} \mathrm{SiBEA}(\mathrm{II})$ & 1.54 & 0.05 & 1891 & 444 & 0.18 & 0.86 \\
$\mathrm{~V}_{3.03} \mathrm{SiBEA}(\mathrm{II})$ & 3.03 & 0.08 & 1164 & 415 & & \\
${ }^{a} \mathrm{~V}$ and Al content by ICP. ${ }^{b}$ Evaluated by the $t$-plot method.
\end{tabular}

$\mathrm{kHz}$ field modulation and a 2.5-5.0 Gauss standard modulation width. The spectra were recorded at $298 \mathrm{~K}$ (room temperature) and at liquid nitrogen temperature (77 $\mathrm{K})$, using an insertion Dewar. Computer simulation of the spectra was performed using the EPRsim 32 program. ${ }^{14}$

A U-shaped reactor equipped with an EPR tube and a UVvis cell, along with high vacuum glass-metal stoppers, allowed us to perform the thermal treatments and subsequent EPR and UV-vis measurements while controlling the inner pressure conditions.

DR UV-vis spectra were recorded in an ambient atmosphere on a Cary 5000 Varian spectrometer equipped with a double integrator by subtraction of polytetrafluoroethylene reference spectrum.

${ }^{51} \mathrm{~V}$ NMR spectra were recorded with a Bruker Avance 500 spectrometer at $131.6 \mathrm{MHz}$ and with a $2.5 \mathrm{~mm}$ zirconia rotor, spinning at $30 \mathrm{kHz}$. The spectra were acquired with spin-echo pulse sequence $(\pi / 2-\tau-\pi-\tau), \pi / 2$ pulse duration of 1.5 $\mu \mathrm{s}$, a recycle delay of $0.5 \mathrm{~s}$, and between 30000 and 100000 accumulations. The $\tau$ delay used for recording the ${ }^{51} \mathrm{~V}$ MAS NMR spectra was $33 \mu \mathrm{s}$. Chemical shifts of vanadium were measured with reference to $\mathrm{NH}_{4} \mathrm{VO}_{3}(\delta=-570 \mathrm{ppm})$.

$\mathrm{X}$-ray photoelectron spectroscopy (XPS) measurements were performed with a Omicron (ESCA+) spectrometer, using an $\mathrm{Al} \mathrm{K} \alpha(h \nu=1486.6 \mathrm{eV}) \mathrm{X}$-ray source. The power of the X-ray source was $300 \mathrm{~W}$. The area of the analyzed sample was $3 \mathrm{~mm}^{2}$. The powder samples were pressed on an indium foil and mounted on a special holder. Binding energy (BE) was measured with reference to $\mathrm{C} 1 \mathrm{~s}$ at $284.7 \mathrm{eV}$, corresponding to carbon contamination. All spectra were fitted with a Voigt function (a 70/30 composition of Gaussian and Lorentzian functions) to determine the number of components under each XPS peak.

2.3. Catalytic Activity Measurement. Propene epoxidation tests were performed under atmospheric pressure in a glass reactor (10 $\mathrm{mm}$ i.d.) using a continuous-flow system in the temperature range of $653-703 \mathrm{~K}$. The reactant mixture containing propene ( 99.5 vol \% purity, Linde), $\mathrm{N}_{2} \mathrm{O}$ (99.995 vol \% purity, Messer), and helium ( $\geq 99.9999$ vol \% purity, Linde) as the diluent was passed through a fixed bed containing the catalyst sample (sieve fraction of $0.3-0.5$ $\mathrm{mm}$ ). Before catalytic tests, $0.50 \mathrm{~g}$ of catalyst was pretreated in helium flow $\left(12.5 \mathrm{~cm}^{3} \mathrm{~min}^{-1}\right)$ at $673 \mathrm{~K}$ for $30 \mathrm{~min}$. The feed gas composition of propene, $\mathrm{N}_{2} \mathrm{O}$, and helium was controlled by mass flow controllers (MFC Brooks). The reactor inlet composition was the following: $15 \mathrm{~mL} \min ^{-1} \mathrm{~N}_{2} \mathrm{O}, 1 \mathrm{~mL}$

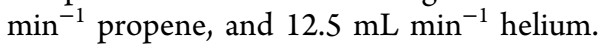

All reaction products were analyzed on-line using gas chromatographs (GC). To prevent condensation of the products, all lines and valves connecting the outlet of the reactor with the GC were heated to $393 \mathrm{~K}$. Remaining propene and organic products (propene oxide (PO), propionaldehyde (PA), acrolein (ACR), and acetone (ACT)) were separated by a WCOT fused silica capillary column $(50 \mathrm{~m} \mathrm{x} 0.53 \mathrm{~mm})$ on a Varian CP-3800 chromatograph equipped with a flame ionization detector. The separation and detection of $\mathrm{N}_{2} \mathrm{O}$, $\mathrm{C}_{3} \mathrm{H}_{6}$, and $\mathrm{CO}_{x}\left(\mathrm{CO}\right.$ and $\left.\mathrm{CO}_{2}\right)$ were performed using a Porapak QS packed column on a SRI 8610C apparatus equipped with a thermal conductivity detector (TCD). The calculation of catalytic activity was described elsewhere, ${ }^{15}$ and it was evaluated from the concentrations of the products detected (i.e., propene oxide, acrolein, acetone, propionaldehyde, $\mathrm{CO}$, and $\mathrm{CO}_{2}$ ) and the remaining propene.

Turn over frequency (TOF) was evaluated on the basis of the amount of propene (in moles) transformed to propene oxide related to vanadium present in the studied zeolites, expressed in moles per second. ${ }^{16}$

The results recorded after $20 \mathrm{~min}$ of the reaction were typically shown and used for discussion, unless otherwise stated.

\section{RESULTS AND DISCUSSION}

3.1. Materials Characterization. The vanadium contents found by ICP-OES in the $\mathrm{V}_{x} \mathrm{SiBEA}$ (II) series prepared by the two-step postsynthesis preparation procedure without washing with distilled water were in general accordance with the expected concentrations (0.91, 1.54, and $3.03 \mathrm{~V}$ wt \%). In contrast, the $\mathrm{V}$ contents in the $\mathrm{V}_{x} \operatorname{SiBEA}(\mathrm{I})$ series, prepared by the two-step postsynthesis preparation procedure with washing with distilled water, were somewhat lower and found to be $0.94,1.22$, and $1.52 \mathrm{~V}$ wt \%, respectively (Table 1 ).

$\mathrm{N}_{2}$ adsorption/desorption experiments were performed to investigate the porosity of the vanadium-modified BEA zeolite. Results are given in Table 1 . The presented isotherms of the SiBEA support and $\mathrm{V}_{x} \mathrm{SiBEA}(\mathrm{I})$ (Figure $1 \mathrm{~A}$ ) and $\mathrm{V}_{x} \mathrm{SiBEA}(\mathrm{II}$ ) (Figure 1B) series of catalysts are of type I, which indicates that the microporous structure of SiBEA was preserved after introduction of vanadium atoms, regardless of the applied method of postsynthesis modification. The surface area of the SiBEA support used for the preparation of both series of catalysts is $512 \mathrm{~m}^{2} \mathrm{~g}^{-1}$. The decrease in the surface area observed for the vanadium-containing samples might be explained by some blocking of the zeolite micropores after vanadium incorporation. The volume of micropores of the SiBEA zeolite was calculated on the basis of the $t$-plot method as equal to $0.20 \mathrm{~mL} \mathrm{~g}^{-1}$, and it decreases up to about $0.18 \mathrm{~mL}$ $\mathrm{g}^{-1}$ for vanadium-containing samples. The $\mathrm{V}$ surface density of the studied samples determined on the basis of the value of surface area and vanadium content (estimated on the grounds 

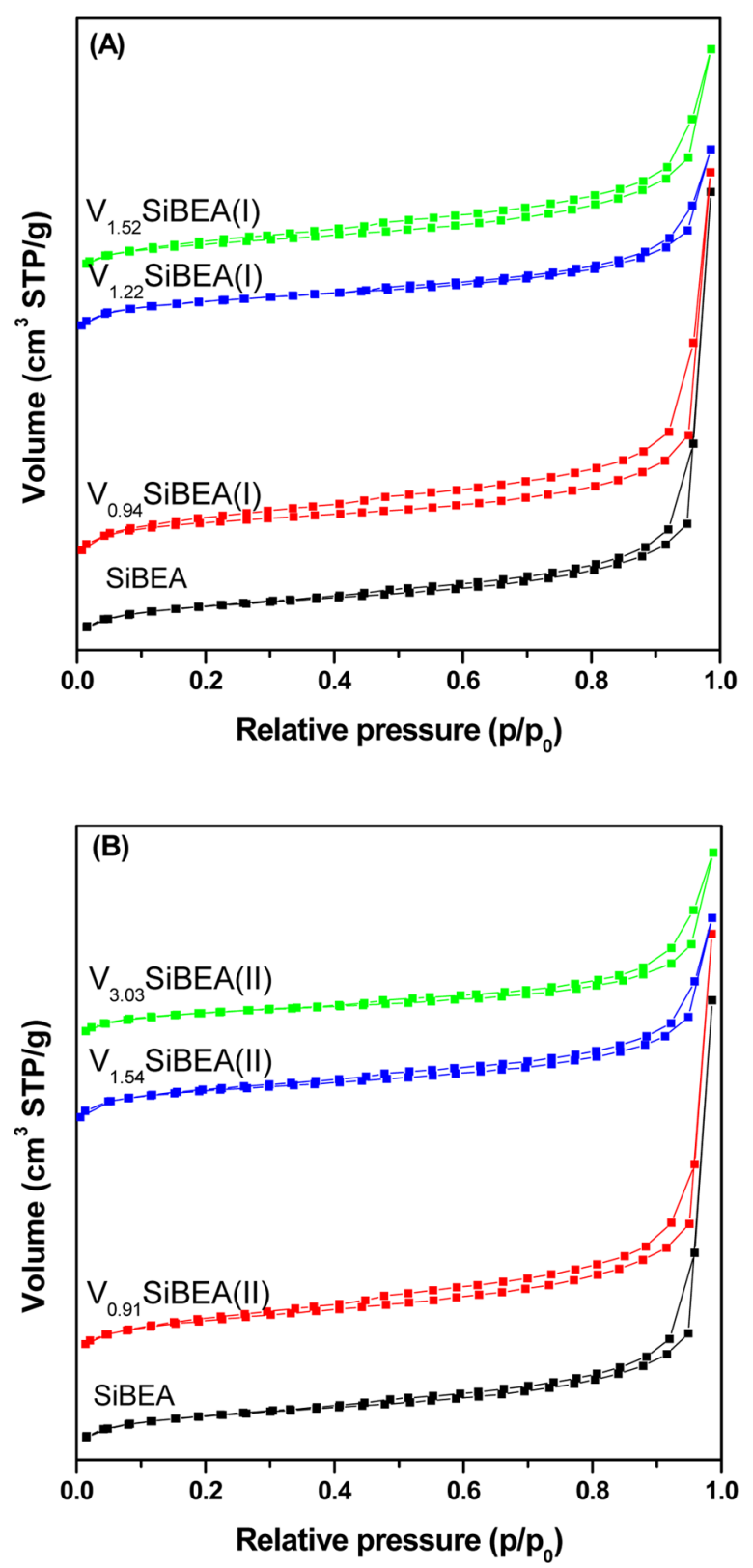

Figure 1. Nitrogen adsorption/desorption isotherms for parent SiBEA and vanadium-modified (A) $\mathrm{V}_{x} \mathrm{SiBEA}$ (I) and (B) $\mathrm{V}_{x} \mathrm{SiBEA}$ (II) series.

of ICP-OES method) were found to be between 0.27 and 0.89 $\mathrm{V}_{\text {atoms }} \mathrm{nm}^{-2}$.

To characterize the reducibility of the vanadium species generated in both $\mathrm{V}_{x} \mathrm{SiBEA}(\mathrm{I})$ and $\mathrm{V}_{x} \mathrm{SiBEA}(\mathrm{II})$ series of catalysts, $\mathrm{H}_{2}$-TPR experiments were performed. TPR profiles of the studied catalysts comprise two reduction peaks in the range of 700-800 and 850-950 K (Figure 2A,B). These two maxima indicate the presence of at least two different forms of vanadium species: the higher temperature peak can be assigned to framework vanadium, whereas the lower temperature peak indicates the presence of extra-framework vanadium species, which is consistent with an earlier report. ${ }^{17}$ The content of the extra-framework vanadium species increases along with the increase of vanadium concentration, in line with ${ }^{51} \mathrm{~V}$ NMR and DR UV-vis studies.
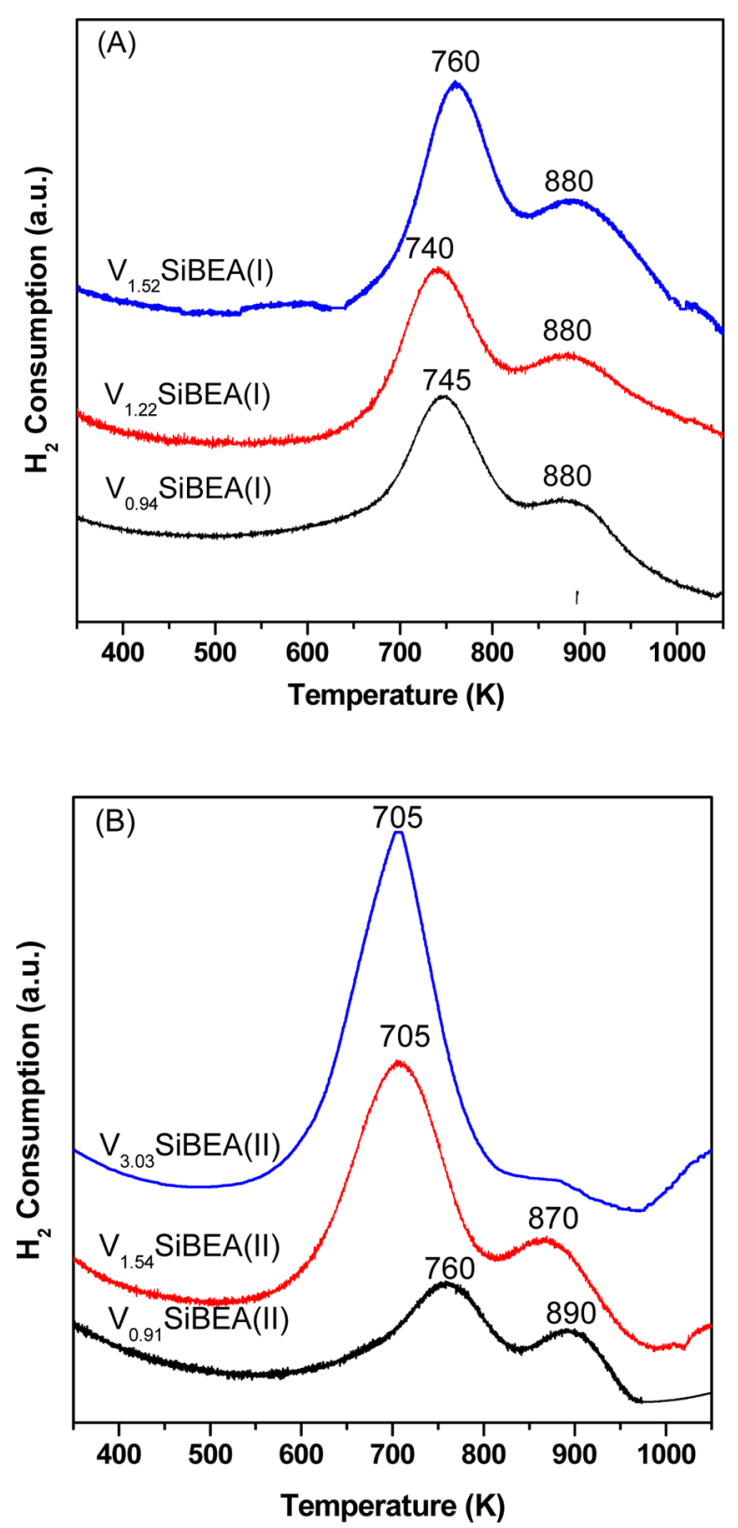

Figure 2. $\mathrm{H}_{2}$-TPR profiles of vanadium species supported on SiBEA zeolites: (A) $\mathrm{V}_{x} \mathrm{SiBEA}(\mathrm{I})$ and (B) $\mathrm{V}_{x} \mathrm{SiBEA}$ (II) series.

Reduction temperatures of the $\mathrm{V}_{x} \mathrm{SiBEA}(\mathrm{II})$ series of catalysts comprising 1.54 and 3.03 wt $\%$ of vanadium were recorded at lower temperatures ( 705 vs $740-760 \mathrm{~K}$ and 870 vs $880 \mathrm{~K})$, when compared to $\mathrm{V}_{x} \operatorname{SiBEA}(\mathrm{I})$. The rather strong decrease in the low temperature peak $(705 \mathrm{~K})$ suggests the presence of easily reducible extra-framework vanadium species. In the $\mathrm{V}_{0.91} \mathrm{SiBEA}(\mathrm{II})$ sample, comprising indeed a lower vanadium concentration, both reduction maxima recorded are shifted to higher temperatures, indicating its lower susceptibility to reduction. The position of the maximum for this sample (Figure 2B, $760 \mathrm{~K}$ ) corresponding to extra-framework vanadium species is very similar to the maxima observed for the $\mathrm{V}_{x} \mathrm{SiBEA}(\mathrm{I})$ series (Figure $2 \mathrm{~A}$ ) at $740-760 \mathrm{~K}$.

The FTIR spectrum of SiBEA, in the range of $\mathrm{OH}$ groups, is shown in Figure 3. According to this figure, the FTIR spectrum of SiBEA exhibits three bands at 3736,3709 , and $3520 \mathrm{~cm}^{-1}$ due to isolated internal, terminal internal, and hydrogen bonded $\mathrm{SiO}-\mathrm{H}$ located in vacant $\mathrm{T}$-atom sites forming hydroxyl nests, in agreement with earlier assignment. ${ }^{8,18}$ After bringing SiBEA into contact with aqueous $\mathrm{NH}_{4} \mathrm{VO}_{3}$ 


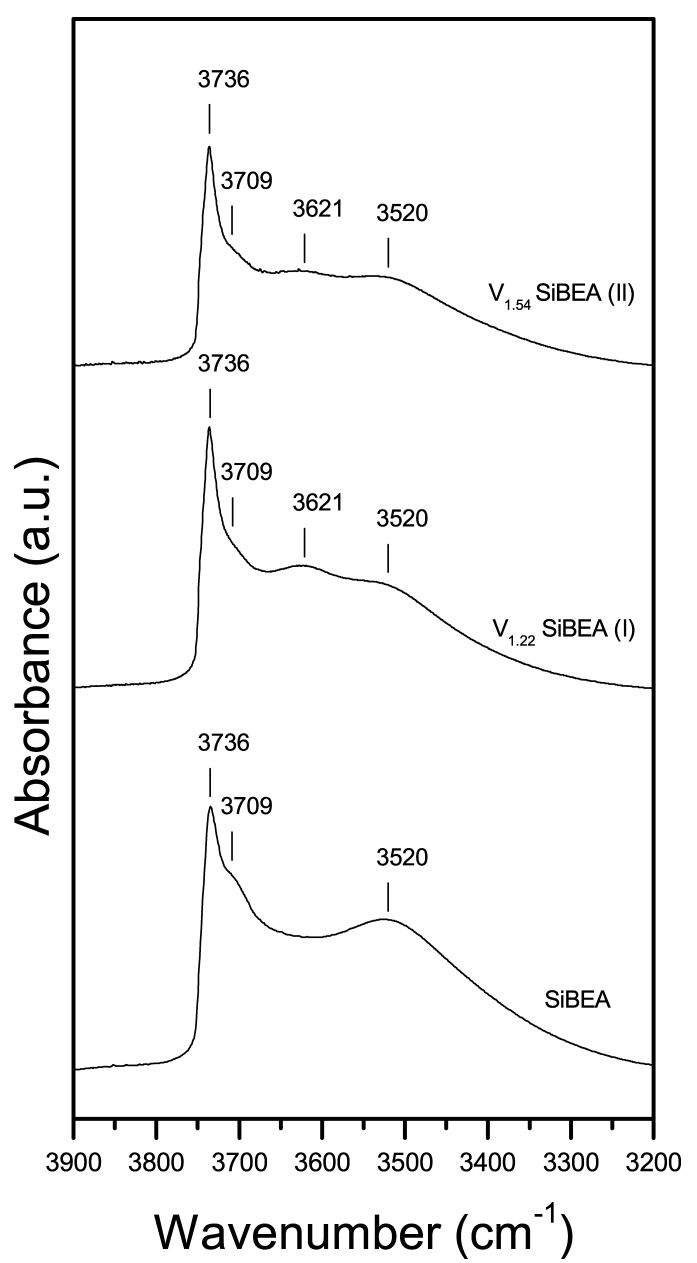

Figure 3. FTIR spectra recorded at room temperature of SiBEA and $\mathrm{V}_{1.22} \mathrm{SiBEA}(\mathrm{I})$ and $\mathrm{V}_{1.54} \mathrm{SiBEA}(\mathrm{II})$ in the vibrational range of the $\mathrm{OH}$ group.

solution at $\mathrm{pH} 2.7$, the intensity of the broad band near 3520 $\mathrm{cm}^{-1}$ decreases, suggesting that hydrogen bonded $\mathrm{SiO}-\mathrm{H}$ groups react with the mononuclear $\mathrm{VO}_{2}{ }^{+}$ions, ${ }^{13}$ leading to the incorporation of these vanadium ions into the SiBEA zeolite framework, in line with earlier works on VSiBEA zeolites. ${ }^{8,18} \mathrm{~A}$ new broad band at about $3621 \mathrm{~cm}^{-1}$ appears in $\mathrm{V}_{1.22} \mathrm{SiBEA}(\mathrm{I})$ and $\mathrm{V}_{1.54} \mathrm{SiBEA}(\mathrm{II})$, due the hydroxyl vibrator of the $\mathrm{V}(\mathrm{V}) \mathrm{O}-$ $\mathrm{H}$ group of pseudo-tetrahedral hydroxylated $(\mathrm{SiO})_{2}(\mathrm{HO}) \mathrm{V}(\mathrm{V})$ species, in line with earlier reports. ${ }^{19,20}$

To determine the nature, amount, and strength of acidic centers in parent HAlBEA, dealuminated BEA (SiBEA), $\mathrm{V}_{1.22} \mathrm{SiBEA}(\mathrm{I})$ and $\mathrm{V}_{1.54} \mathrm{SiBEA}(\mathrm{II})$ zeolite samples, the adsorption of pyridine as a probe molecule was performed. The amounts of Brønsted and Lewis acidic centers in parent HAlBEA, dealuminated BEA (SiBEA) and V-containing SiBEA $\left(\mathrm{V}_{1.22} \mathrm{SiBEA}(\mathrm{I})\right.$ and $\left.\mathrm{V}_{1.54} \mathrm{SiBEA}(\mathrm{II})\right)$ zeolite samples are presented in Table 2. Figures 4 and 5 show the FTIR spectra of HAlBEA, SiBEA, $\mathrm{V}_{1.22} \mathrm{SiBEA}(\mathrm{I})$ and $\mathrm{V}_{1.54} \mathrm{SiBEA}(\mathrm{II})$ after adsorption of pyridine at room temperature and the subsequent desorption by outgassing for $1 \mathrm{~h}$ under vacuum of $10^{-3} \mathrm{~Pa}$ at room temperature (Figure 4) and then at $423 \mathrm{~K}$ (Figure 5). Several IR bands are observed at 1637, 1620, 1598, $1578,1546,1490,1454$, and $1446 \mathrm{~cm}^{-1}$ for parent HAlBEA and are related to Brønsted acidic centers (the bands at 1637 and $1546 \mathrm{~cm}^{-1}$ ), strong Lewis acidic centers (the bands at 1620 and $1454 \mathrm{~cm}^{-1}$ ), Brønsted and Lewis acidic centers (the
Table 2. Amounts of Brønsted and Lewis Acidic Centers Determined from the Amount of Pyridine Remaining Adsorbed after Outgassing the Samples at $298 \mathrm{~K}$ for $1 \mathrm{~h}$

\begin{tabular}{lcc}
\multicolumn{1}{c}{ sample } & $\begin{array}{c}\text { Brønsted acidic centers } \\
\left(\mu \mathrm{mol} \mathrm{g}^{-1}\right)^{a, b}\end{array}$ & $\begin{array}{c}\text { Lewis acidic centers } \\
\left(\mu \mathrm{mol} \mathrm{g}^{-1}\right)^{a, c}\end{array}$ \\
\hline HAlBEA & 181.1 & 129.3 \\
SiBEA & traces & traces \\
$\mathrm{V}_{1.22} \mathrm{SiBEA}(\mathrm{I})$ & 36.5 & 199.2 \\
$\mathrm{~V}_{1.54} \mathrm{SiBEA}(\mathrm{II})$ & 56.2 & 152.4
\end{tabular}

${ }^{a}$ Quantification of the number of acidic centers in zeolites was done as reported earlier by Emeis. ${ }^{21} b_{\text {The amounts of Brønsted acidic }}$ centers determined from the IR band of $\mathrm{PyH}^{+}$at $1546 \mathrm{~cm}^{-1}$. ${ }^{c}$ The amounts of Lewis acidic centers determined from the IR band of PyL at 1449 and/or $1454 \mathrm{~cm}^{-1}$.

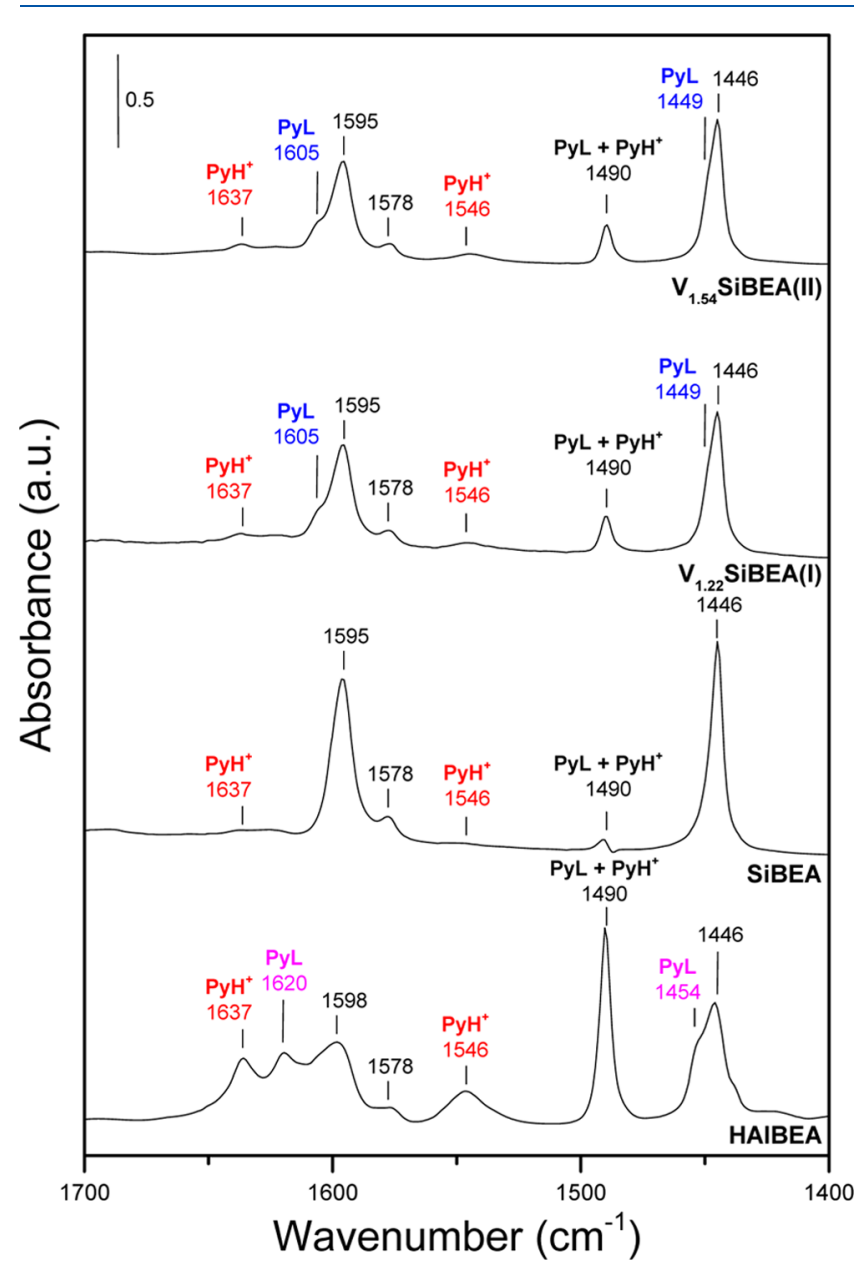

Figure 4. FTIR spectra recorded at room temperature of SiBEA and $\mathrm{V}_{1.22} \mathrm{SiBEA}(\mathrm{I})$ and $\mathrm{V}_{1.54} \mathrm{SiBEA}(\mathrm{II})$ calcined at $723 \mathrm{~K}$ for $3 \mathrm{~h}$ in $\mathrm{O}_{2}(1.6$ $\left.\times 10^{4} \mathrm{~Pa}\right)$ and then outgassed at $573 \mathrm{~K}\left(10^{-3} \mathrm{~Pa}\right)$ for $1 \mathrm{~h}$ after adsorption of pyridine $(133 \mathrm{~Pa})$ for $1 \mathrm{~h}$ at room temperature and desorption at room temperature.

band at $1490 \mathrm{~cm}^{-1}$ ), very weak Lewis acidic centers (hydroxyls), in agreement with earlier reports, ${ }^{8,22}$ and physisorbed pyridine (the band at $1578 \mathrm{~cm}^{-1}$ ). The intense bands at 1595 and $1446 \mathrm{~cm}^{-1}$ indicate that very weak Lewis acidic centers are present in SiBEA. The very small bands typical of pyridinium cations seen for SiBEA at 1545 and 1637 $\mathrm{cm}^{-1}$, indicating the presence of traces of Brønsted acidic centers, probably correspond to the acidic proton of $\mathrm{Al}-$ $\mathrm{O}(\mathrm{H})-\mathrm{Si}$ groups, which are still present after dealumination, 


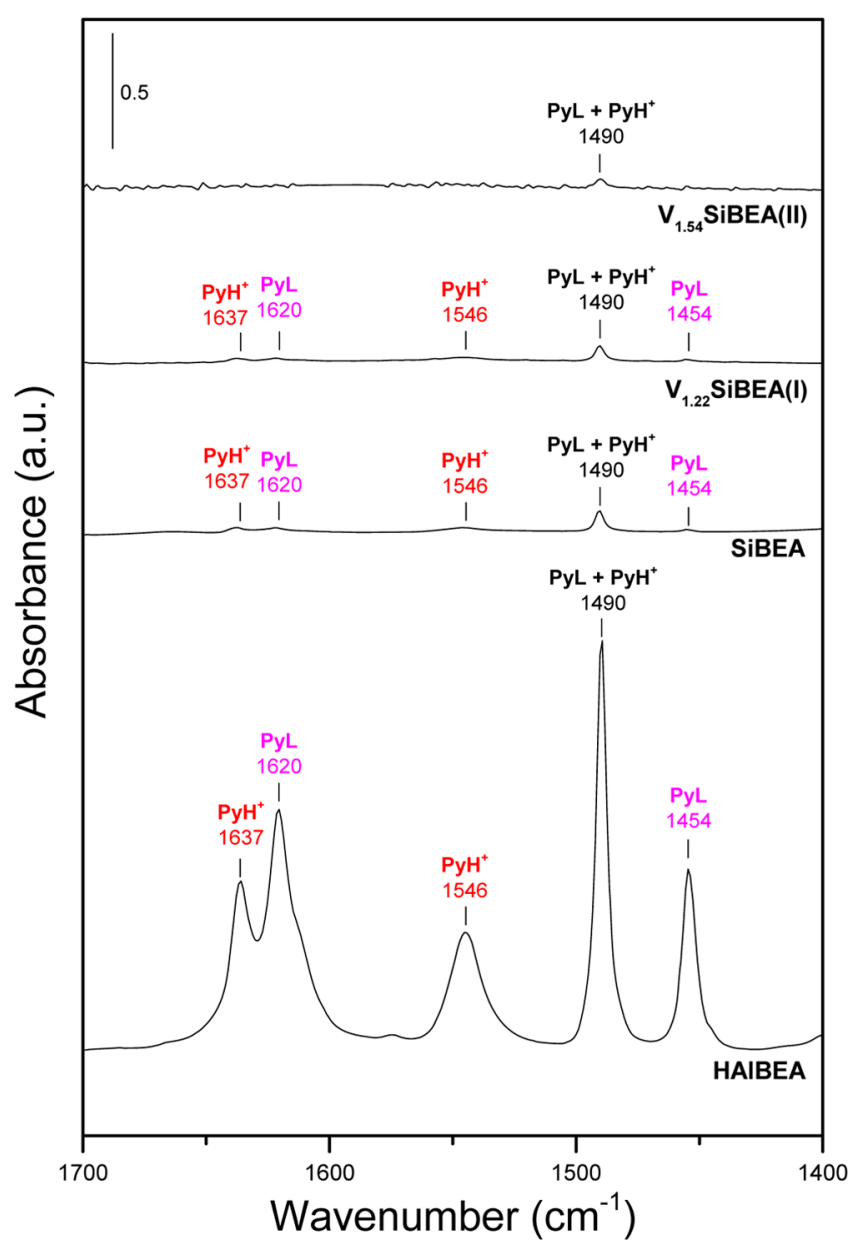

Figure 5. FTIR spectra recorded at room temperature of SiBEA and $\mathrm{V}_{1.22} \mathrm{SiBEA}(\mathrm{I})$ and $\mathrm{V}_{1.54} \mathrm{SiBEA}(\mathrm{II})$ calcined at $723 \mathrm{~K}$ for $3 \mathrm{~h}$ in $\mathrm{O}_{2}(1.6$ $\left.\times 10^{4} \mathrm{~Pa}\right)$ and then outgassed at $573 \mathrm{~K}\left(10^{-3} \mathrm{~Pa}\right)$ for $1 \mathrm{~h}$ after adsorption of pyridine $(133 \mathrm{~Pa})$ for $1 \mathrm{~h}$ at room temperature and desorption at $423 \mathrm{~K}$ for $1 \mathrm{~h}$.

in line with earlier data obtained for BEA zeolites. ${ }^{8}$ After the introduction of vanadium into SiBEA, additional Brønsted and Lewis acidic centers appeared as shown by two bands at 1545 and $1637 \mathrm{~cm}^{-1}$ for $\mathrm{V}_{1.22} \operatorname{SiBEA}(\mathrm{I})$ and $\mathrm{V}_{1.54} \mathrm{SiBEA}(\mathrm{II})$, characteristic of pyridinium cations, whose intensities are higher than that for SiBEA (Figure 4), and new bands at 1605 and $1449 \mathrm{~cm}^{-1}$, corresponding to pyridine interacting with moderate Lewis acidic centers $\left(\mathrm{V}^{5+}\right)$, respectively, in line with earlier reports. ${ }^{8,22}$ As reported earlier for V-containing BEA zeolites, ${ }^{8}$ the Brønsted acidic centers evidenced for both $\mathrm{V}_{1.22} \mathrm{SiBEA}(\mathrm{I})$ and $\mathrm{V}_{1.54} \mathrm{SiBEA}(\mathrm{II})$ zeolite samples are related to the acidic proton of the $\mathrm{OH}$ group of framework hydroxylated $(\mathrm{SiO})_{2}(\mathrm{HO}) \mathrm{V}=\mathrm{O}$ species, as deduced from their disappearance upon adsorption of pyridine (results not shown).

It is important to mention here that in parent HAlBEA there are much higher amounts of Brønsted acidic centers than in both $\mathrm{V}_{1.22} \mathrm{SiBEA}(\mathrm{I})$ and $\mathrm{V}_{1.54} \operatorname{SiBEA}(\mathrm{II})$ (see Table 2). Moreover, the Brønsted acidic centers present in HAlBEA are much stronger than those present in $\mathrm{V}_{1.22} \mathrm{SiBEA}(\mathrm{I})$ and $\mathrm{V}_{1.54} \mathrm{SiBEA}(\mathrm{II})$ because they did not disappear from the IR spectrum of HAlBEA after desorption of pyridine at $423 \mathrm{~K}$ and almost completely disappeared from the IR spectra of the Vcontaining SiBEA samples (see Figure 5). As described above, the different Lewis acidic centers could be determined in the studied zeolite materials: strong Lewis acidic centers (the bands at 1620 and $1454 \mathrm{~cm}^{-1}$ ), moderate Lewis acidic centers (the bands at 1605 and $1449 \mathrm{~cm}^{-1}$ ), and very weak Lewis acidic centers (hydroxyls) (the bands at 1595 and $1446 \mathrm{~cm}^{-1}$ ). The decomposition of the IR bands present in these ranges allows determining the amounts of each kind of Lewis acidic centers in the studied samples (see Table 2). In HAlBEA only very strong Lewis acidic centers are present, as evidenced by the IR band at $1454 \mathrm{~cm}^{-1}$ (see Figures 4 and 5). In SiBEA, a high amount of very weak Lewis acidic centers are detected (the bands at 1595 and $1446 \mathrm{~cm}^{-1}$ ), as shown in Figure 4. In $\mathrm{V}_{1.22} \mathrm{SiBEA}(\mathrm{I})$ and $\mathrm{V}_{1.54} \mathrm{SiBEA}(\mathrm{II})$, moderate Lewis acidic centers (the bands at 1605 and $1449 \mathrm{~cm}^{-1}$ ) and very weak Lewis acidic centers (hydroxyls) (the bands at 1595 and 1446 $\mathrm{cm}^{-1}$ ) are detected, as shown in Figure 4. The decomposition of the bands in this range allows determination of Lewis acidic centers related to $\mathrm{V}^{5+}$, and the results are presented in Table 2.

The nature and environment of the vanadium present in $\mathrm{V}_{x} \operatorname{SiBEA}(\mathrm{I})$ and $\mathrm{V}_{x} \mathrm{SiBEA}(\mathrm{II})$ were investigated using $\mathrm{DR}$ UV-vis, ${ }^{51} \mathrm{~V}$ MAS NMR, and EPR spectroscopies.

The DR UV-vis measurements were carried out for the asprepared $\mathrm{V}_{0.94} \operatorname{SiBEA}(\mathrm{I}), \mathrm{V}_{1.22} \operatorname{SiBEA}(\mathrm{I}), \mathrm{V}_{1.52} \mathrm{SiBEA}(\mathrm{I})$, $\mathrm{V}_{0.91} \mathrm{SiBEA}(\mathrm{II}), \mathrm{V}_{1.54} \mathrm{SiBEA}(\mathrm{II})$, and $\mathrm{V}_{3.03} \mathrm{SiBEA}(\mathrm{II})$ samples (Figure 6). The DR UV-vis spectra of $\mathrm{V}_{0.94} \mathrm{SiBEA}(\mathrm{I})$, $\mathrm{V}_{1.22} \mathrm{SiBEA}(\mathrm{I})$, and $\mathrm{V}_{1.52} \mathrm{SiBEA}(\mathrm{I})$ exhibit two main bands at 265 and $335 \mathrm{~nm}$ attributed to oxygen-to-pseudo-tetrahedral $\mathrm{V}(\mathrm{V})$ charge transfer transitions, involving oxygen in bridging $(\mathrm{V}-\mathrm{O}-\mathrm{Si})$ and terminal $(\mathrm{V}=\mathrm{O})$ positions, respectively, in

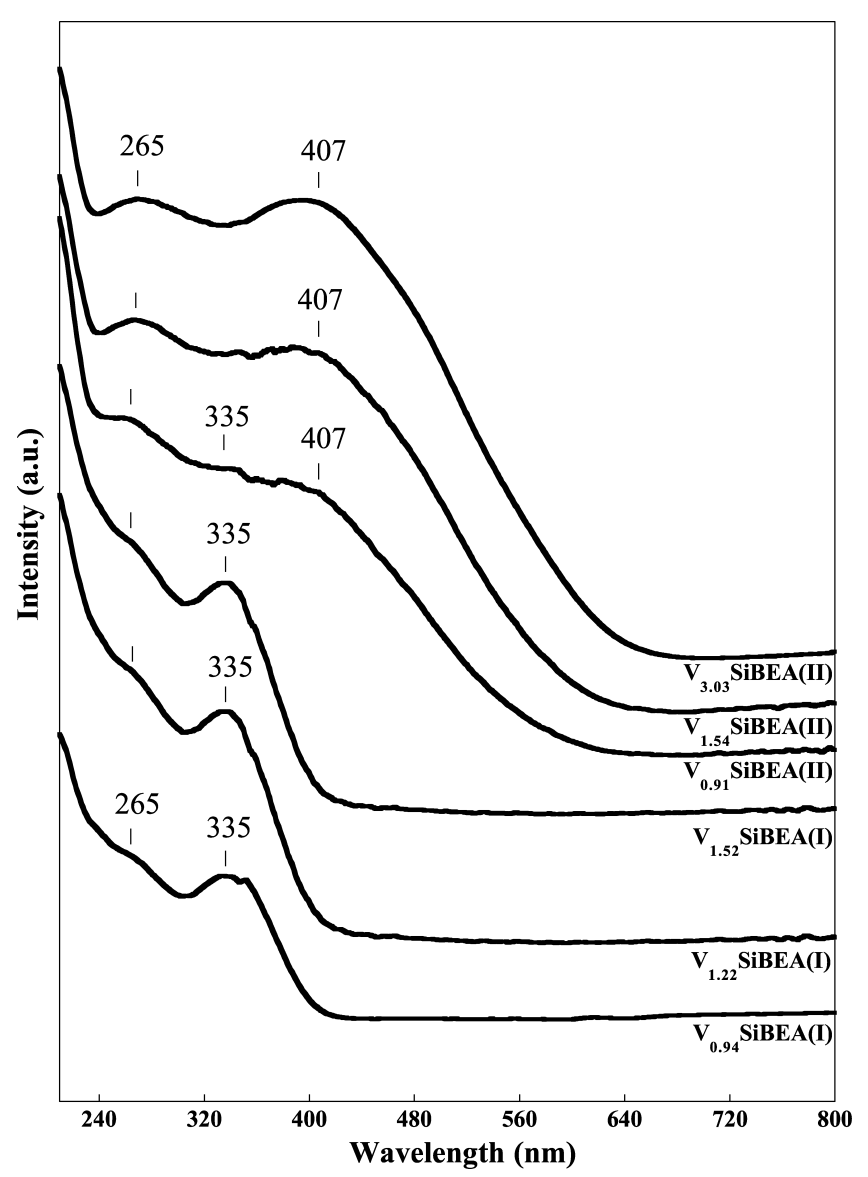

Figure 6. DR UV-vis spectra recorded in an ambient atmosphere of as-prepared $\mathrm{V}_{x} \mathrm{SiBEA}(\mathrm{I})$ and $\mathrm{V}_{x} \mathrm{SiBEA}(\mathrm{II})$ series. 
line with earlier reports. ${ }^{8,9,23}$ In contrast, for as-prepared $\mathrm{V}_{0.91} \mathrm{SiBEA}(\mathrm{II}), \mathrm{V}_{1.54} \mathrm{SiBEA}(\mathrm{II})$, and $\mathrm{V}_{3.03} \mathrm{SiBEA}(\mathrm{II})$, an additional band at $407 \mathrm{~nm}$ appears, whose intensity grows with $\mathrm{V}$ loading, which can be attributed to oxygen-to-pseudooctahedral $\mathrm{V}(\mathrm{V})$ charge transfer transitions, in line with our earlier work. ${ }^{8}$ It clearly shows that the kind of procedure used for the preparation of two series of $\mathrm{V}_{x} \mathrm{SiBEA}(\mathrm{I})$ and $\mathrm{V}_{x} \mathrm{SiBEA}(\mathrm{II})$ samples has a significant influence on the nature and environment of vanadium species introduced in the SiBEA support.

The DR UV-vis spectra of calcined samples, $\mathrm{C}-\mathrm{V}_{0.94} \mathrm{SiBEA}$ (I) (Figure $\mathrm{S} 1 \mathrm{~b}$ ) and $\mathrm{C}-\mathrm{V}_{0.91} \mathrm{SiBEA}(\mathrm{II})$ (Figure $\mathrm{S} 2 \mathrm{~b}$ ), exhibit two bands at 240 and $285 \mathrm{~nm}$. The shift of these DR UV-vis charge-transfer bands to lower wavelengths upon calcination suggests a greater distortion of pseudo-tetrahedral $\mathrm{V}(\mathrm{V})$ species in calcined samples than that in the as-prepared one, in line with earlier work. ${ }^{8,9}$

After reduction of $\mathrm{C}-\mathrm{V}_{0.94} \mathrm{SiBEA}(\mathrm{I})$ (Figure $\mathrm{S} 1 \mathrm{c}$ ) and $\mathrm{C}-$ $\mathrm{V}_{0.91} \mathrm{SiBEA}(\mathrm{II}$ ) (Figure S2c) with hydrogen at $873 \mathrm{~K}$, a significant amount of $\mathrm{V}(\mathrm{IV})$ species is formed, as shown by the appearance of the DR UV-vis bands at 523 and $575 \mathrm{~nm}$. They correspond to $\mathrm{d}-\mathrm{d}$ transitions in $\mathrm{V}(\mathrm{IV})$ species. A simultaneous decrease in the intensity of the broad band in the 240$320 \mathrm{~nm}$ range, with a maximum at 260-268 nm (Figures S1c and S2c), assigned to pseudo-tetrahedral $\mathrm{V}(\mathrm{V})$ species confirms that a significant part of $\mathrm{V}(\mathrm{V})$ species is reduced to $\mathrm{V}(\mathrm{IV})$.

$\mathrm{V}_{0.94} \mathrm{SiBEA}(\mathrm{I})$ and $\mathrm{V}_{0.91} \mathrm{SiBEA}(\mathrm{II})$ have been studied by EPR spectroscopy at room temperature (Figures S3 and S4) and at $77 \mathrm{~K}$ (Figures 7 and 8, Table 3) after successive treatments. As-prepared $\mathrm{V}_{0.94} \mathrm{SiBEA}(\mathrm{I})$ and $\mathrm{V}_{0.91} \mathrm{SiBEA}(\mathrm{II})$ reveal no or very weak EPR signal, respectively, at room temperature or at $77 \mathrm{~K}$, indicating at best trace amounts of paramagnetic V(IV) ions, as shown in Figures S3, S4, 7, and 8, spectrum (a). In contrast, after thermal treatments under vacuum at $773 \mathrm{~K}, \mathrm{EPR}$ spectra of both samples reveal intense V(IV) signals recorded at room temperature (Figures S3 and S4, spectra (b)) and at $77 \mathrm{~K}$ (Figures 7 and 8, spectra (b)). Both signals are different in terms of EPR parameters ( $g$-factors and hyperfine coupling constants), indicating that the V(IV) species observed in both samples are different, in line with our earlier reports, ${ }^{24}$ and can be explained by $\mathrm{V}(\mathrm{IV})$ species presenting very different relaxation times. The species observed at room temperature in very small amounts are consistent with pseudo-octahedral $\mathrm{V}(\mathrm{IV})$ species, whereas the fast-relaxing species that require low temperature $(77 \mathrm{~K})$ to be observed in EPR and that represent the very large majority of $\mathrm{V}(\mathrm{IV})$ species formed upon thermal treatment under vacuum are pseudo-tetrahedral $\mathrm{V}(\mathrm{IV})$ : such a fast relaxation process, commonly observed for $3 \mathrm{~d}^{1}$ species in a pseudo-tetrahedral environment, has been attributed to the presence of excited low-lying states. ${ }^{25}$

Oxidizing conditions $\left(773 \mathrm{~K}\right.$ under static $150 \mathrm{mbar}^{\mathrm{O}_{2}}$ ) result in a strong reduction of the total amount of $\mathrm{V}(\mathrm{IV})$, as shown in Figures S3, S4, 7, and 8, spectra (c). In contrast, the amount of pseudo-tetrahedral V(IV) species increased upon further applying reducing conditions ( $873 \mathrm{~K}$ under $\mathrm{H}_{2}$ flow), as shown by Figures 7 and 8, spectra (d), whereas the amount of pseudo-octahedral V(IV) species still remained very low (Figures S3 and S4, spectra (d)). The successive formation and consumption of pseudo-tetrahedral V(IV) species upon reduction and oxidation treatments, respectively, point out an easy and reversible $\mathrm{V}(\mathrm{V})$ to $\mathrm{V}(\mathrm{IV})$ redox reaction. One should note from EPR results that pseudo-tetrahedral V(IV) species

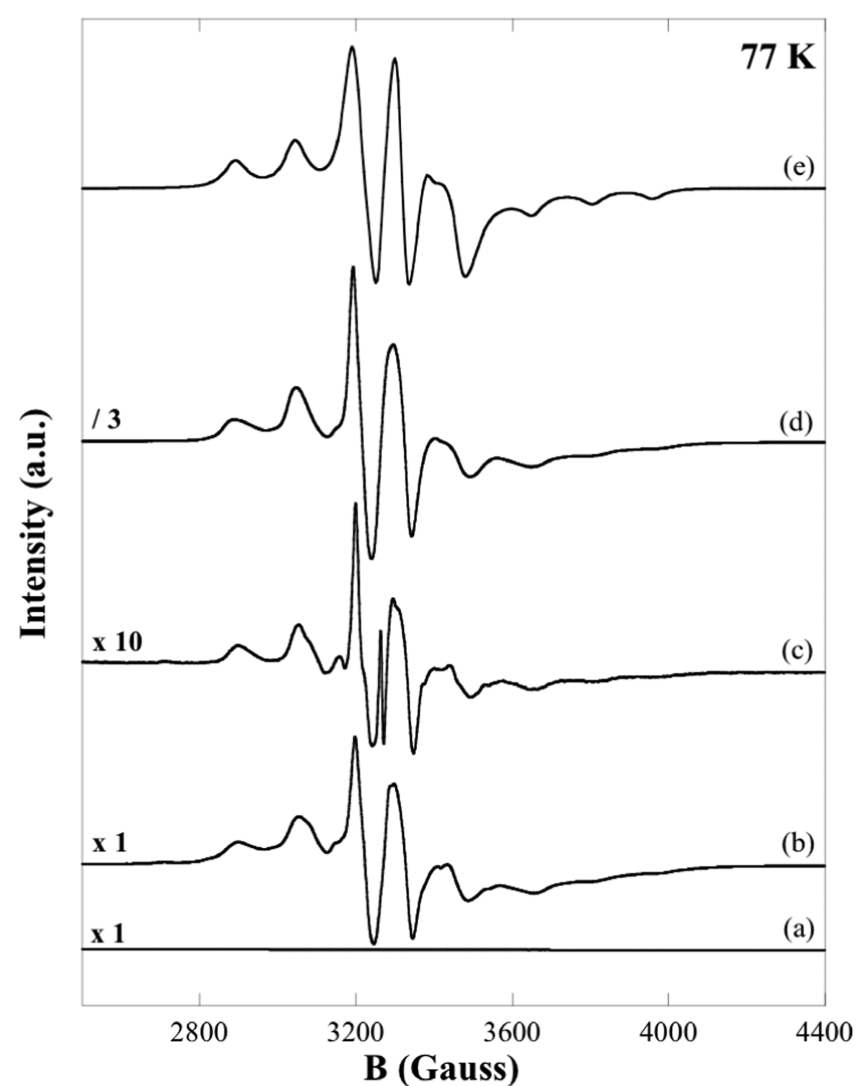

Figure 7. EPR spectra recorded at $77 \mathrm{~K}$ of $\mathrm{V}_{0.94} \mathrm{SiBEA}(\mathrm{I})$ (a) as prepared, (b) treatment at $773 \mathrm{~K}$ under vacuum, (c) treatment at 773 $\mathrm{K}$ under $150 \mathrm{mbar}_{2}$, then treatment at $873 \mathrm{~K}$ under $\mathrm{H}_{2}$ flow for $1 \mathrm{~h}$, (d) experimental and (e) simulated.

are formed in both $\mathrm{V}_{0.94} \mathrm{SiBEA}(\mathrm{I})$ and $\mathrm{V}_{0.91} \mathrm{SiBEA}(\mathrm{II})$ samples after treatment at $773 \mathrm{~K}$ under vacuum and in flowing hydrogen at $873 \mathrm{~K}$. In the case of the $\mathrm{V}_{0.94} \mathrm{SiBEA}(\mathrm{I})$ sample, an additional isotropic signal is observed at $g=2.0$, which significantly decreases after successive thermal treatments and seems to arise from carbonaceous radical species.

NMR is a powerful tool for structural characterization of local environment of vanadium in solid samples, as shown in an earlier report. ${ }^{26}$ In the ${ }^{51} \mathrm{~V}$ MAS NMR spectrum of $\mathrm{V}_{0.94} \mathrm{SiBEA}(\mathrm{I})$ (Figure 9), only one peak is observed at -628 $\mathrm{ppm}$, related to the presence of isolated pseudo-tetrahedral $\mathrm{V}(\mathrm{V})$ species, in line with earlier work. ${ }^{22}$ In contrast, in the spectrum of $\mathrm{V}_{1.52} \mathrm{SiBEA}(\mathrm{I})$, the main peak at $-628 \mathrm{ppm}$ also appears but with a much weaker peak at $-765 \mathrm{ppm}$, probably related to a new framework pseudo-tetrahedral $\mathrm{V}(\mathrm{V})$ species. In the ${ }^{51} \mathrm{~V}$ MAS NMR spectra of $\mathrm{V}_{0.91} \operatorname{SiBEA}(\mathrm{II})$ and $\mathrm{V}_{3.03} \mathrm{SiBEA}(\mathrm{II})$ (Figure 9), two peaks are present related to the framework pseudo-tetrahedral $\mathrm{V}(\mathrm{V})$ species (peak at -628) and an extra-framework pseudo-octahedral V(V) species (peak at $-550 \mathrm{ppm}$ ), respectively, in line with earlier reports. ${ }^{19,22}$ The presence of these two kinds of vanadium species is confirmed by two spinning sidebands marked with * and $* *$ in Figure 9. The second framework pseudo-tetrahedral $\mathrm{V}(\mathrm{V})$ species at $-765 \mathrm{ppm}$ may be present, but it is not observable because it is superimposed on the spinning sidebands of the signal at $-550 \mathrm{ppm}$.

Results of XPS experiments for selected as-prepared $\mathrm{V}_{0.94} \mathrm{SiBEA}(\mathrm{I}), \mathrm{V}_{0.91} \mathrm{SiBEA}(\mathrm{II}), \mathrm{V}_{1.52} \mathrm{SiBEA}(\mathrm{I})$, and $\mathrm{V}_{3.03}$ SiBEA(II) samples are presented in Figures S5-S8. Figure S5 shows 


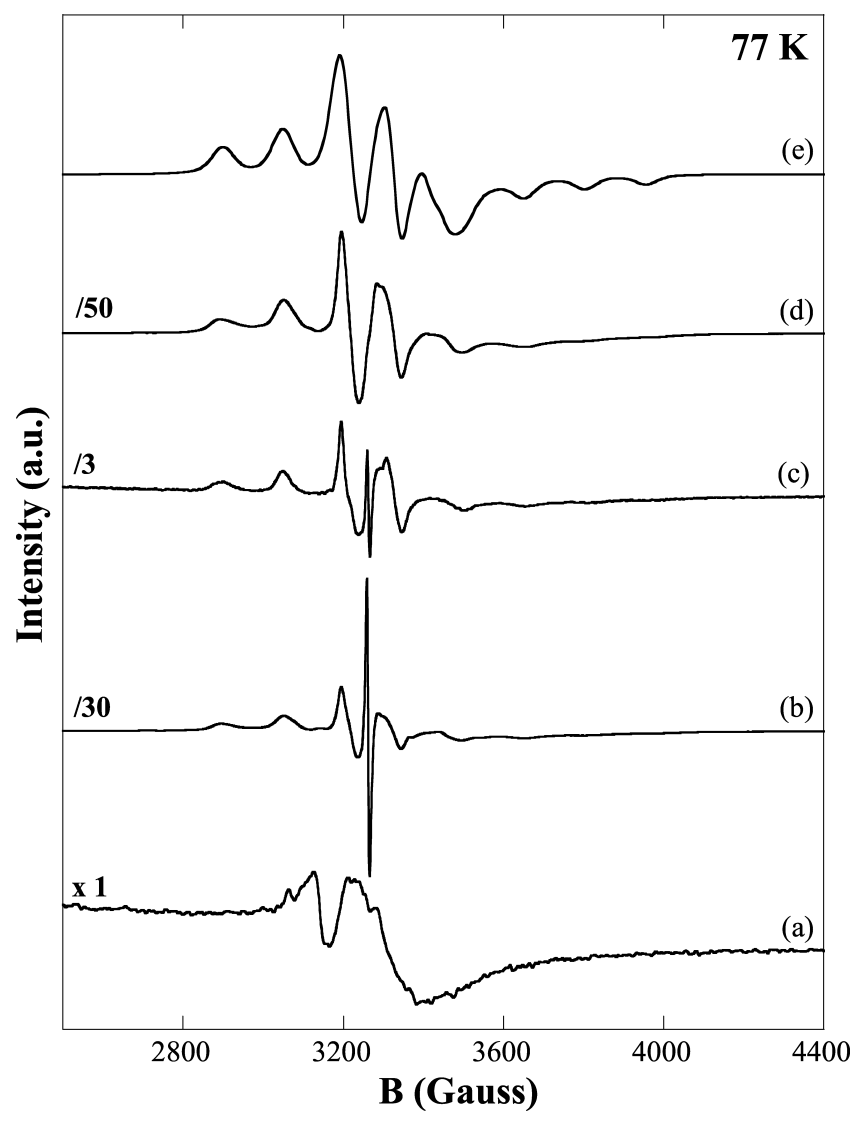

Figure 8. EPR spectra recorded at $77 \mathrm{~K}$ of $\mathrm{V}_{0.91} \operatorname{SiBEA}(\mathrm{II})$ (a) as prepared, (b) treatment at $773 \mathrm{~K}$ under vacuum, (c) treatment at 773 $\mathrm{K}$ under $150 \mathrm{mbar}_{2}$ and then treatment at $873 \mathrm{~K}$ under $\mathrm{H}_{2}$ flow for $1 \mathrm{~h},(\mathrm{~d})$ experimental and (e) simulated.

the XP spectra of $\mathrm{V}_{0.94} \mathrm{SiBEA}(\mathrm{I}), \mathrm{V}_{0.91} \mathrm{SiBEA}(\mathrm{II}), \mathrm{V}_{1.52} \mathrm{SiBEA}$ (I), and $\mathrm{V}_{3.03} \mathrm{SiBEA}(\mathrm{II})$ in the $\mathrm{C} 1 \mathrm{~s}$ core range, and all of them are composed of four peaks at $284.7 \mathrm{eV}$ (organic contaminants), $285.8 \mathrm{eV}$ (C-O groups), $287.0 \mathrm{eV}(\mathrm{C}=\mathrm{O}$ groups), and 289.0-289.3 eV (carbonates). The obtained $\mathrm{BE}$ values of $\mathrm{O} 1 \mathrm{~s}(533 \mathrm{eV})$ (Figure S7) and Si 2p (103.9 eV) (Figure S8) are typical of a zeolite structure and very close to that reported for ZSM-5 and ERI zeolites. ${ }^{22,27}$

$\mathrm{XP}$ spectra of the $\mathrm{V}_{0.94} \mathrm{SiBEA}(\mathrm{I}), \mathrm{V}_{0.91} \mathrm{SiBEA}(\mathrm{II}), \mathrm{V}_{1.52} \mathrm{SiBEA}$ (I), and $\mathrm{V}_{3.03} \mathrm{SiBEA}(\mathrm{II})$ samples (Figure $\mathrm{S} 6$ ) are composed of pairs of peaks in both $\mathrm{V} 2 \mathrm{p}_{3 / 2}$ and $\mathrm{V} 2 \mathrm{p}_{1 / 2}$ ranges, suggesting the presence of two types of vanadium surface species. These two ranges of $\mathrm{BE}$ values of $\mathrm{V} 2 \mathrm{p}_{3 / 2}$ and $\mathrm{V} 2 \mathrm{p}_{1 / 2}$ show that vanadium in these samples is present in the $(\mathrm{V})$ oxidation state. Among each pair of peaks, the most intense peaks for $\mathrm{V}$ $2 \mathrm{p}_{3 / 2}$ and $\mathrm{V} 2 \mathrm{p}_{1 / 2}$ present $\mathrm{BE}$ values close to 517 and $524 \mathrm{eV}$, respectively, which seem to indicate the preponderance of pseudo-tetrahedral $\mathrm{V}(\mathrm{V})$ species in all samples. However, the weaker second peaks for $\mathrm{V} 2 \mathrm{p}_{3 / 2}$ and $\mathrm{V} 2 \mathrm{p}_{1 / 2}$ with $\mathrm{BE}$ values close to 519 and $526 \mathrm{eV}$, respectively, reveal that other types of $\mathrm{V}(\mathrm{V})$ species are also present, though in minor amounts, in the

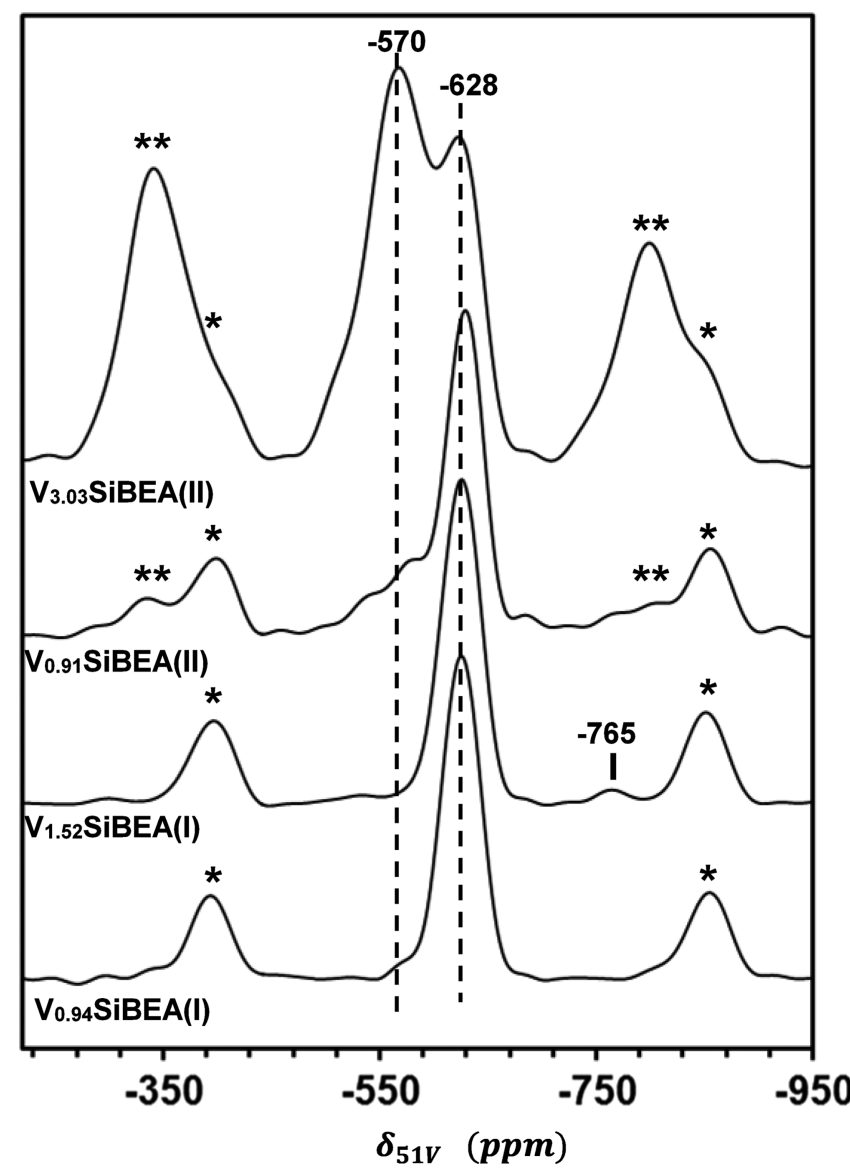

Figure 9. ${ }^{51} \mathrm{~V}$ MAS NMR spectra recorded at room temperature of $\mathrm{V}_{0.94} \mathrm{SiBEA}(\mathrm{I}), \mathrm{V}_{1.52} \mathrm{SiBEA}(\mathrm{I}), \mathrm{V}_{0.91} \mathrm{SiBEA}(\mathrm{II})$, and $\mathrm{V}_{3.03} \mathrm{SiBEA}(\mathrm{II})$ in a $2.5 \mathrm{~mm}$ (external diameter) zirconia rotor; (* and $* *$ ) spinning sidebands.

$\mathrm{V}_{0.94} \operatorname{SiBEA}(\mathrm{I}), \mathrm{V}_{0.91} \operatorname{SiBEA}(\mathrm{II}), \mathrm{V}_{1.52} \operatorname{SiBEA}(\mathrm{I})$, and $\mathrm{V}_{3.03}$ SiBEA(II) samples. Such values may be ascribed to polynuclear $\mathrm{V}(\mathrm{V})$. The much higher intensity of the peak at 519.1 for $\mathrm{V}_{3.03} \mathrm{SiBEA}(\mathrm{II})$ than that for $\mathrm{V}_{1.52} \mathrm{SiBEA}(\mathrm{I})$, being in line with DR UV-vis results (Figure 6), strongly supports such an assignment.

3.2. Catalytic Activity. Vanadium-modified SiBEA zeolites have been tested as catalysts for propene epoxidation with $\mathrm{N}_{2} \mathrm{O}$ as an oxidant. The influence of the environment of vanadium ions as well as their concentration and also availability to reagents is discussed on the basis of catalytic results and wide physicochemical characterization. According to an earlier paper, ${ }^{18}$ and consistently to characterization presented above, vanadium ions incorporated into the SiBEA structure are mainly stabilized in two distinct tetrahedral environments. One of them constitutes a stable vanadyl group and another one coordinates one hydroxyl group. The two tetrahedral vanadium species differ with the step of distortion, as demonstrated by previous photoluminescence and UV-vis measurements ${ }^{9}$ and

Table 3. Simulated EPR Parameters of Pseudo-Tetrahedral V(IV) Species Observed at $77 \mathrm{~K}^{a}$

$\begin{array}{cccccc}\text { sample } & g_{z} & g_{x} & g_{y} & A_{z} \text { (Gauss) } & A_{x}(\text { Gauss }) \\ \mathrm{V}_{0.94} \operatorname{SiBEA}(\mathrm{I}) & 1.901 & 1.963 & 1.941 & 153 & 34 \\ \mathrm{~V}_{0.91} \operatorname{SiBEA}(\mathrm{II}) & 1.900 & 1.972 & 1.939 & 151 & 28\end{array}$

${ }^{a}$ See spectrum (e) in Figures 8 and 9 for simulated spectra according to these parameters. 

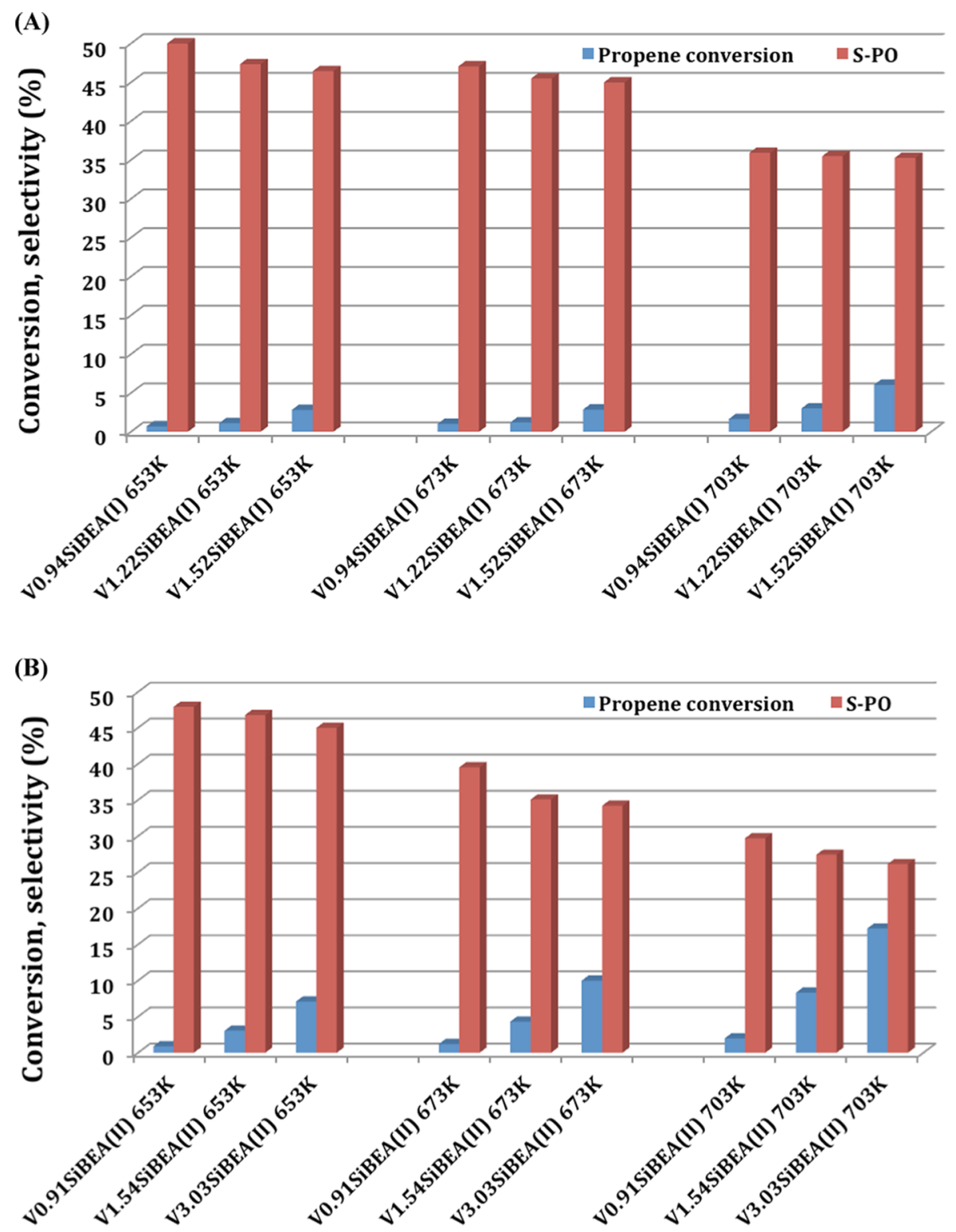

Figure 10. Catalytic activity (propene conversion and selectivity to PO: propene oxide) of $\mathrm{V}_{x} \mathrm{SiBEA}(\mathrm{I})$ (A) and $\mathrm{V}_{x} \mathrm{SiBEA}(\mathrm{II})$ (B) in propene epoxidation at different reaction temperatures: 653, 673, and $703 \mathrm{~K}$.

our DR UV-vis spectra. Additionally, some amounts of octahedral vanadium species have also been noted.

It has been shown earlier that vanadium species in tetrahedral coordination are especially active in selective propene epoxidation, with $\mathrm{N}_{2} \mathrm{O}$ as an oxidant, owing to the presence of a partial positive charge on the vanadium ion resulting in the adsorption of $\mathrm{N}_{2} \mathrm{O}$ in its mesomeric form $\mathrm{N}^{\delta-}=\mathrm{N}^{\delta+}=\mathrm{O}$, resulting in the formation of weakly electrophilic oxygen. ${ }^{7,28}$ Such an electrophilic oxygen has also been indicated as playing a key role in propene epoxidation performed on silver catalysts ${ }^{29}$ and on iron-modified mesoporous silicas. ${ }^{28,30}$

Considering this, two different series of vanadiumcontaining SiBEA zeolite catalysts, comprising vanadium species of different nature and diverse content, were tested for propene epoxidation with $\mathrm{N}_{2} \mathrm{O}$ as an oxidant. The activity of both series of vanadium catalysts differs, depending on the preparation procedure, reaction temperature, and also on vanadium concentration and vanadium species structure.
All $\mathrm{V}_{x} \mathrm{SiBEA}$ samples ( $\mathrm{I}$ and $\mathrm{II}$ ) are active in propene conversion, which quite strongly increases with the reaction temperature and vanadium content. Regardless of the condition of the preparation procedure, the conversion of propene to propene oxide is quite remarkable, with a selectivity to propene oxide (PO) of about $44-50 \%$ at $653 \mathrm{~K}$. PO selectivity then decreases along with the increase in reaction temperature, down to $35-25 \%$ at $703 \mathrm{~K}$ (Figure 10A,B, red bars). Besides $\mathrm{PO}$, other organic oxygen-bearing products, such as propionaldehyde (PA), acetone (ACT), and acrolein (ACR), were also detected in sizable amounts (Figure 11). According to our earlier studies on propene epoxidation with $\mathrm{N}_{2} \mathrm{O}$ over vanadium-modified mesoporous structures, propene oxide, propionaldehyde, and acetone are the primary products when $\mathrm{N}_{2} \mathrm{O}$ adsorption leads to the formation of mildly electrophilic oxygen species $\left(\mathrm{N}^{\delta-}=\mathrm{N}^{\delta+}=\mathrm{O}\right){ }^{31}$ As shown in Figure 11 (blue bars), propionaldehyde selectivity followed the same tendency as PO, and it decreased slowly with increasing reaction temperature, whereas acetone selectivity (green bars) 

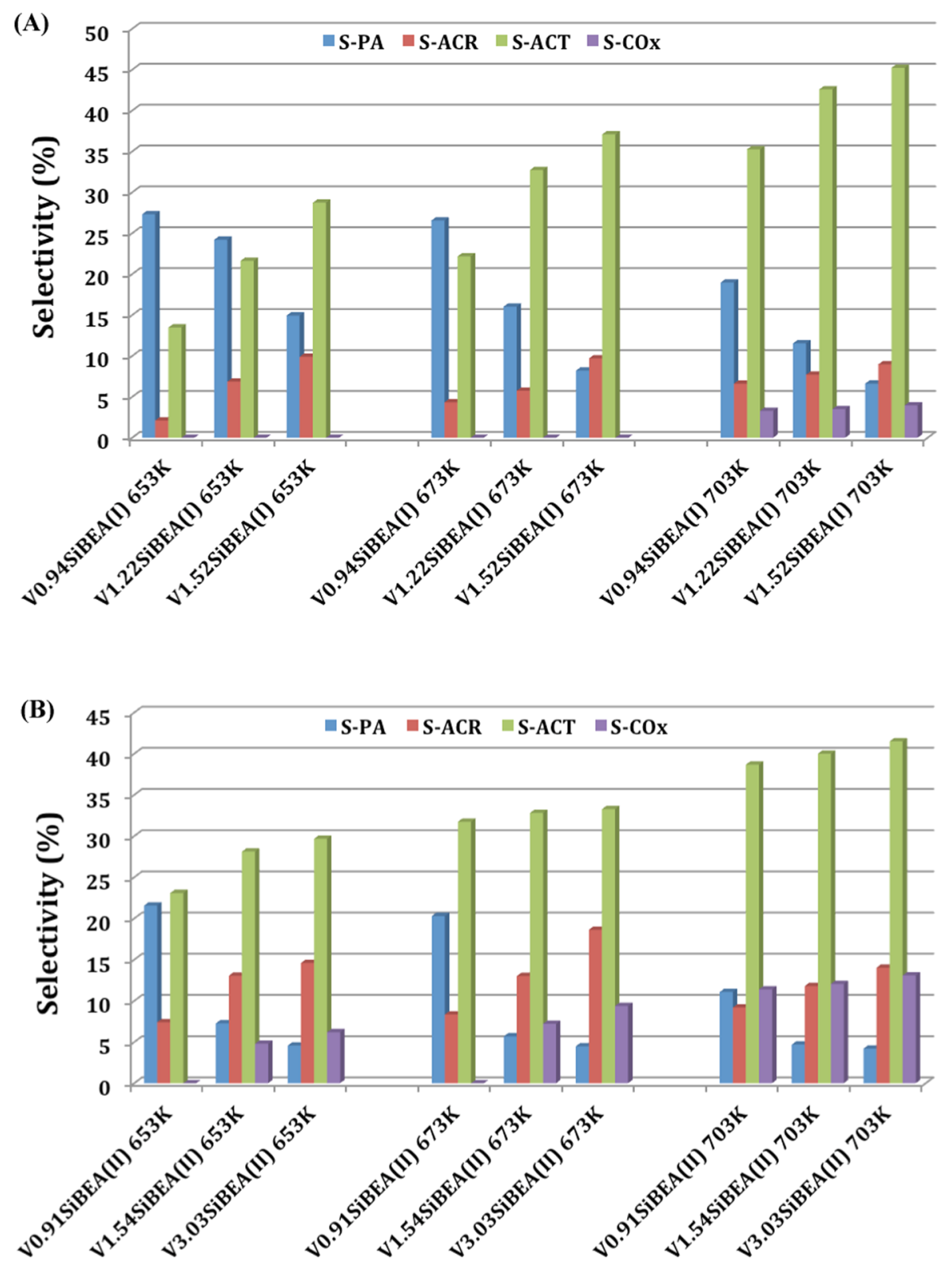

Figure 11. Selectivity to oxygen-bearing products (PA: propionaldehyde, ACR: acrolein, ACT: acetone, and $\left.\mathrm{CO}_{x}: \mathrm{CO}, \mathrm{CO}_{2}\right)$ of $\mathrm{V}_{x} \mathrm{SiBEA}(\mathrm{I})(\mathrm{A})$ and $\mathrm{V}_{x} \mathrm{SiBEA}(\mathrm{II})(\mathrm{B})$ in propene epoxidation at different reaction temperatures: 653,673 , and $703 \mathrm{~K}$.

increased. One should note that, according to our findings ${ }^{34}$ and also to literature data, ${ }^{32,33}$ acetone can also be formed as a result of propene oxide and propionaldehyde isomerization, so that the increase in acetone selectivity with increasing reaction temperature probably indicates increased isomerization of $\mathrm{PO}$ and propionaldehyde at higher temperatures. As for acetone, acrolein selectivity also increases with increasing reaction temperature.

Although the selectivity to PO is only slightly affected by the vanadium contents, selectivity to other oxygen-bearing products strongly varies. Propionaldehyde is the main side product at lower reaction temperature $(653 \mathrm{~K})$ for both I and II series of zeolite catalysts with low vanadium contents (below 1 wt \%) and its selectivity decreases along with the increase in the reaction temperature (Figures 11 and S9). However, for catalysts with higher vanadium content (about $1.5 \mathrm{wt} \%$ ), acetone is the main side product at $653 \mathrm{~K}$ and even the main product at $703 \mathrm{~K}$ (Figures 11 and S9). According to $\mathrm{Li}$ and
Shen, ${ }^{34}$ the formation of acetone during propene oxidation over supported vanadium catalysts is affected by the number and strength of acidic sites. The authors indicate that propene interacts with the $-\mathrm{V}-\mathrm{O}-\mathrm{H}$ species with the subsequent formation of isopropoxy species $\left(-\mathrm{O}-\mathrm{CH}\left(\mathrm{CH}_{3}\right)_{2}\right)$, which are subsequently transformed into acetone, which is strongly adsorbed on Lewis acidic sites. Considering that the studied $\mathrm{V}_{x}$ SIBEA catalysts contain weak and medium acidic sites, acetone may be easily desorbed, thus explaining the high and increasing selectivity to acetone with temperature increase (Figure 11). Along with the increase in the reaction temperature, selectivity to acetone also increases with the vanadium concentration, at the expense of propionaldehyde and PO selectivity. This may be explained as increasing the vanadium concentrations of the catalysts leads to increasing the acidity of the catalysts, thus bringing higher content of acetone as a product of $\mathrm{PO}$ and $\mathrm{PA}$ isomerization. 
(A)

Propene conversion (\%) $\quad$ S-PO

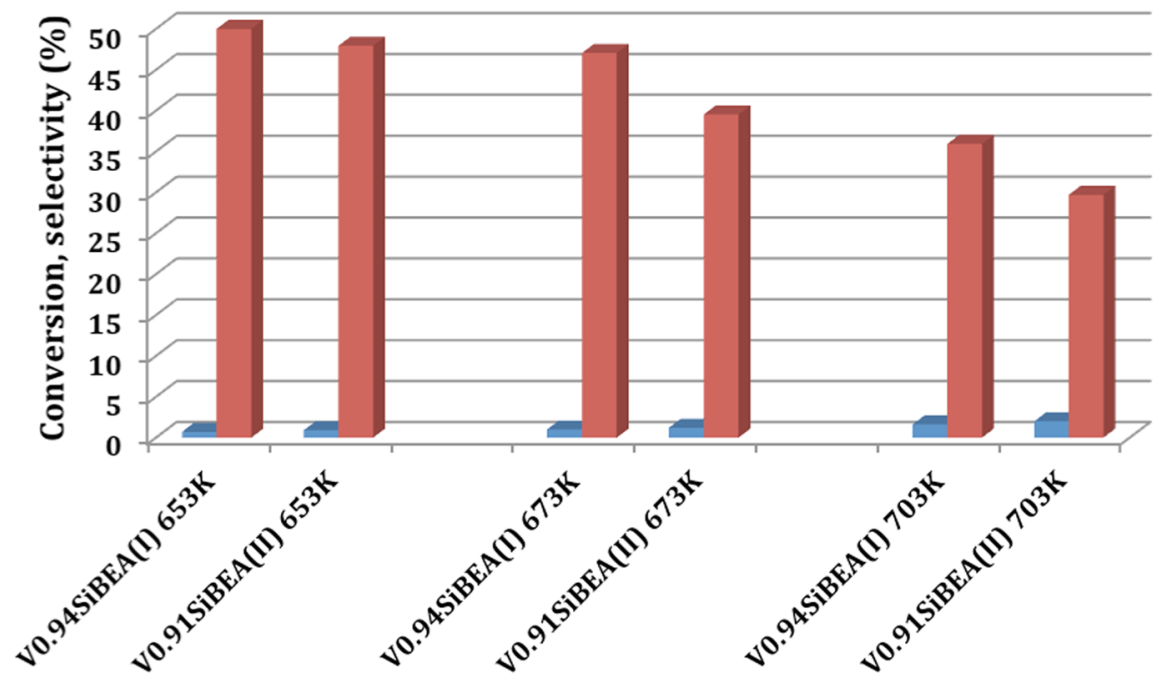

(B)

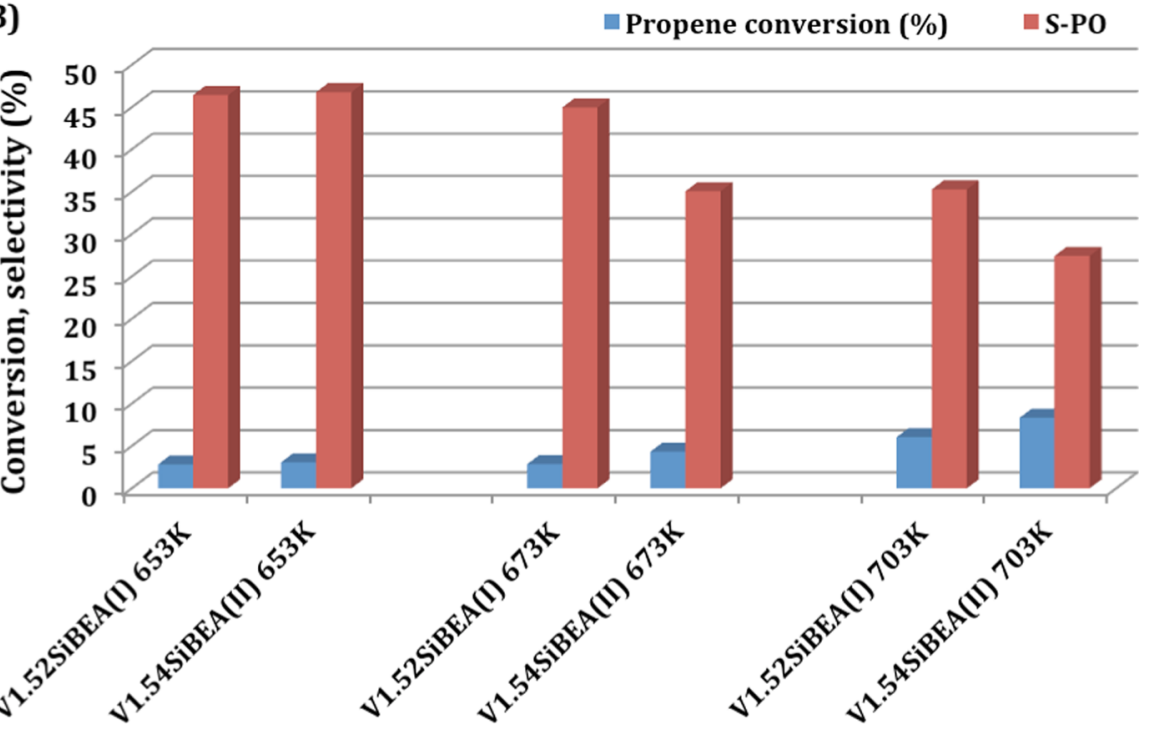

Figure 12. Catalytic activity (propene conversion and selectivity to PO: propene oxide) of $\mathrm{V}_{0.94} \operatorname{SiBEA}(\mathrm{I})$ and $\mathrm{V}_{0.91} \mathrm{SiBEA}(\mathrm{II})$ (A) and $\mathrm{V}_{1.52} \mathrm{SiBEA}(\mathrm{I})$ and $\mathrm{V}_{1.54} \mathrm{SiBEA}(\mathrm{II})(\mathrm{B})$ in propene epoxidation at different reaction temperatures: 653, 673, and $703 \mathrm{~K}$.

In Figures 12 and S9, the activity of two different series of catalysts comprising similar vanadium concentration (about 0.9 and 1.5 wt $\%$ of $\mathrm{V}$ ) is compared. The $\mathrm{V}_{0.94} \mathrm{SiBEA}(\mathrm{I})$ catalyst comprising vanadium located mainly in the framework of the zeolite structure showed lower propene conversion when compared to the $\mathrm{V}_{0.91} \mathrm{SiBEA}$ (II) sample. It is in accordance with the earlier studies pointing out the lower availability to reagents of part of vanadium species incorporated into the zeolite structure. ${ }^{9}$ Increasing the vanadium content (up to 1.5 wt \%), introduced by the two different postsynthesis procedures, brings about higher propene conversion owing to the higher concentration of the easily available vanadium species (Figure 12A,B). However, as for $\mathrm{V}_{0.94} \operatorname{SiBEA}(\mathrm{I})$ and $\mathrm{V}_{0.91} \mathrm{SiBEA}(\mathrm{II})$ samples, higher propene conversion was noted for $\mathrm{V}_{1.54} \mathrm{SiBEA}(\mathrm{II})$ compared to $\mathrm{V}_{1.52} \mathrm{SiBEA}(\mathrm{I})$, even though part of vanadium species in the $\mathrm{V}_{x} \mathrm{SiBEA}(\mathrm{II})$ series possess octahedral coordination. Such higher propene conversion may result from easier access of reagents to vanadium species in the $\mathrm{V}_{x} \mathrm{SiBEA}(\mathrm{II})$ series of catalysts. On the other hand, selectivity to propene oxide was higher on the $\mathrm{V}_{x} \operatorname{SiBEA}(\mathrm{I})$ series when compared to that on the $\mathrm{V}_{x} \mathrm{SiBEA}(\mathrm{II})$ series. This is consistent with earlier results pointing out the very high activity of isolated vanadium species in the interaction with nitrous oxide with the subsequent formation of mildly electrophilic oxygen species active in epoxide formation.

The activity of both I and II series of catalysts was also estimated taking into account an amount of propene transformed into propene oxide related to the number of vanadium species per second (expressed as turn over frequency-TOF). On the basis of analysis of ${ }^{51} \mathrm{~V}$ NMR spectra (Figure 9), in $\mathrm{V}_{x} \mathrm{SiBEA}(\mathrm{I})$, vanadium is present mainly as framework pseudo-tetrahedral $\mathrm{V}(\mathrm{V})$ species, whereas in $\mathrm{V}_{x} \operatorname{SiBEA}(\mathrm{II})$, both framework pseudo-tetrahedral $\mathrm{V}(\mathrm{V})$ and extra-framework pseudo-octahedral $\mathrm{V}(\mathrm{V})$ are present. Considering the low vanadium concentration (up to $0.86 \mathrm{~V}_{\text {atom }} \mathrm{nm}^{-2}$ ), according to Wachs et al., ${ }^{35}$ we can assume that all of these centers are located on the surface as a monolayer coverage. Majority of these centers appear as isolated ones, as was 
concluded on the basis of ${ }^{51} \mathrm{~V}$ NMR (Figure 9) and DR UVvis (Figure 6) measurements. Even though $\mathrm{V}_{x} \operatorname{SiBEA}(\mathrm{I})$ catalysts comprise vanadium mainly in pseudo-tetrahedral coordination, their activity for propene epoxidation expressed as TOF, characterizing the activity of the particular active site, was lower when compared to that of $\mathrm{V}_{x} \mathrm{SiBEA}(\mathrm{II})$ (Figures 13

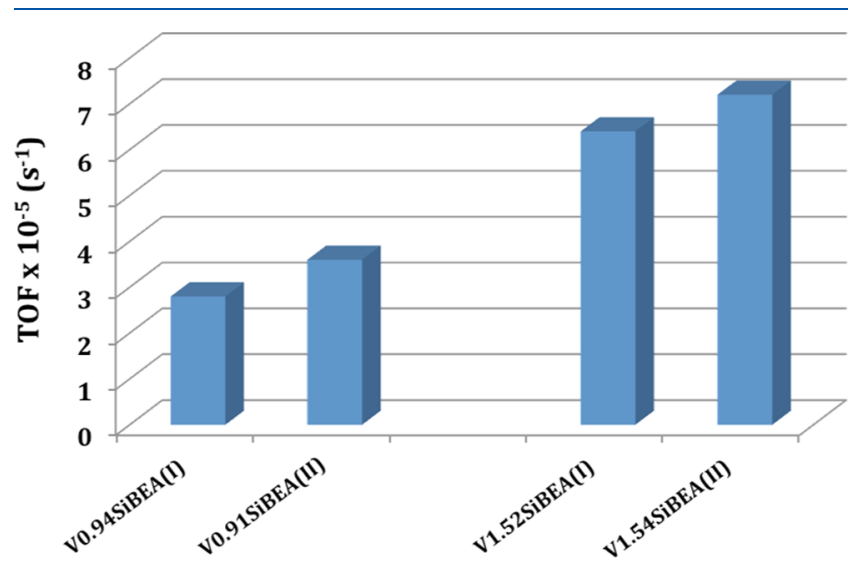

Figure 13. Comparison of specific activity expressed as turn over frequency (TOF) for propene epoxidation toward propene oxide on $\mathrm{V}_{x} \mathrm{SiBEA}(\mathrm{I})$ and $\mathrm{V}_{x} \mathrm{SiBEA}(\mathrm{II})$ with comparable vanadium concentration; reaction temperature $653 \mathrm{~K}$.

and S10), especially for samples with low V content. It can be explained on the basis of the earlier study concerning the photoluminescence spectroscopy, ${ }^{9}$ indicating that the vanadium species incorporated into the zeolite BEA structure with low concentration are mainly located in sites poorly accessible to reagents, such as $\mathrm{S} 1$ sites in the five membered rings of the BEA structure. It may thus result in limited contact of such vanadium species with reagents and may explain the lower activity (expressed in propene conversion and also as TOF) of the $\mathrm{V}_{x} \mathrm{SiBEA}(\mathrm{I})$ series of catalysts when compared to that of the $\mathrm{V}_{x} \mathrm{SiBEA}(\mathrm{II})$ one. The growing activity for epoxidation reaction with increasing vanadium content (Figures 13 and S10) may be explained considering the location of additional vanadium species in easily available sites, such as S2 sites in the 12-membered rings.

The I and II series of catalysts differ significantly as far as the selectivity toward total oxidation products $\left(\mathrm{CO}\right.$ and $\left.\mathrm{CO}_{\mathrm{x}}\right)$ is concerned. The $\mathrm{V}_{x} \mathrm{SiBEA}(\mathrm{I})$ series do not show any activity in the total oxidation reaction up to $673 \mathrm{~K}$ (Figure 11A), whereas the $\mathrm{V}_{x} \mathrm{SiBEA}(\mathrm{II})$ series show the formation of $\mathrm{CO}_{x}$ already at $653 \mathrm{~K}$ exceeding even $10 \%$ at $703 \mathrm{~K}$ (Figure 11B). This is consistent with earlier reports pointing on oligomeric vanadium species as the centers responsible for the total oxidation reaction, ${ }^{36}$ keeping in mind that DR UV-vis and ${ }^{51} \mathrm{~V}$ MAS NMR measurements confirmed the presence of polynuclear extra-framework pseudo-octahedral $\mathrm{V}(\mathrm{V})$ species only in the $\mathrm{V}_{x} \mathrm{SiBEA}(\mathrm{II})$ samples. Selectivity to $\mathrm{CO}_{x}$ was also affected by vanadium concentration. Catalysts with low vanadium loading (below 1 wt \%) did not show any combustion products up to $673 \mathrm{~K}$ regardless of the method of modification with vanadium. Low concentration of vanadium indeed limits the formation of polynuclear pseudooctahedral $\mathrm{V}(\mathrm{V})$ species responsible for propene total oxidation. In addition, low vanadium concentration imposes a longer distance between the isolated vanadium species, which stimulates PO formation as a kinetically favored product and limits its further transformation, especially toward total oxidation.

\section{CONCLUSIONS}

The combined use of TPR, DR UV-vis, FTIR, ${ }^{51} \mathrm{~V}$ MAS NMR, EPR, and XPS allowed us to determine the nature and environment of vanadium in two series of $\mathrm{V}$-containing SiBEA zeolites prepared by a two-step postsynthesis procedure with washing $\left(\mathrm{V}_{x} \mathrm{SiBEA}(\mathrm{I})\right.$ series $)$ and without washing $\left(\mathrm{V}_{x} \mathrm{SiBEA}\right.$ (II) series).

The characterization of $\mathrm{V}_{x} \operatorname{SiBEA}(\mathrm{I})$ and $\mathrm{V}_{x} \mathrm{SiBEA}(\mathrm{II})$ series reveals the formation of various forms of vanadium species depending on the $\mathrm{V}$ concentration and conditions applied upon preparation of each series: as evidenced by DR UV-vis and ${ }^{51} \mathrm{~V}$ MAS NMR in the $\mathrm{V}_{x} \operatorname{SiBEA}(\mathrm{I})$ series, vanadium is present mainly as mononuclear framework pseudo-tetrahedral $\mathrm{V}(\mathrm{V})$ species. In contrast, in the $\mathrm{V}_{x} \mathrm{SiBEA}(\mathrm{II})$ series, vanadium is present as mononuclear framework pseudo-tetrahedral and polynuclear extra-framework pseudo-octahedral $\mathrm{V}(\mathrm{V})$ species.

As shown by EPR, the oxidation state of $\mathrm{V}$ species easily changes upon outgassing under vacuum at $773 \mathrm{~K}$, calcination in oxygen, and treatment with hydrogen at high temperature $(873 \mathrm{~K})$.

The presence of Brønsted and Lewis acidic centers was evidenced in both $\mathrm{V}_{x} \mathrm{SiBEA}(\mathrm{I})$ and $\mathrm{V}_{x} \mathrm{SiBEA}(\mathrm{II})$ series by FTIR spectroscopy with pyridine used as the probe molecule.

The catalytic activity tests in propene epoxidation evidenced that the highly dispersed mononuclear framework pseudotetrahedral $\mathrm{V}(\mathrm{V})$ species are responsible for high selectivity to propene oxide, whereas polynuclear extra-framework pseudooctahedral $\mathrm{V}(\mathrm{V})$ species catalyzed mainly total oxidation.

The $\mathrm{V}_{x} \mathrm{SiBEA}(\mathrm{I})$ series of catalysts with vanadium present mainly as mononuclear framework pseudotetrahedral $\mathrm{V}(\mathrm{V})$ species showed lower TOF values than the $\mathrm{V}_{x} \mathrm{SiBEA}$ (II) series with vanadium present as mononuclear framework pseudotetrahedral $\mathrm{V}(\mathrm{V})$ species and polynuclear extra-framework pseudo-octahedral $\mathrm{V}(\mathrm{V})$, demonstrating that, apart from highly dispersed isolated vanadium species, the availability of vanadium species to reagents also plays an important role in the gas-phase propene epoxidation.

\section{ASSOCIATED CONTENT}

\section{S Supporting Information}

The Supporting Information is available free of charge on the ACS Publications website at DOI: 10.1021/acs.jpcc.8b05731.

DR UV-vis spectra recorded in an ambient atmosphere (Figures S1 and S2), EPR spectra recorded at room temperature (Figures S3 and S4), XP spectra (Figures S5-S8), selectivity to oxygen-bearing products (PA: propionaldehyde, ACR: acrolein, ACT: acetone, and $\mathrm{CO}_{x}: \mathrm{CO}, \mathrm{CO}_{2}$ ) (Figure S9), comparison of specific activities expressed as turn over frequencies (TOF) (Figure S10) (PDF)

\section{AUTHOR INFORMATION}

\section{Corresponding Authors}

*E-mail: awaclaw@amu.edu.pl. Tel: +48 618291791 (A.H.).

*E-mail: stanislaw.dzwigaj@upmc.fr. Tel: +33 144272113 (S.D.).

\section{ORCID}

Agnieszka Held: 0000-0002-5658-6974 


\section{Notes}

The authors declare no competing financial interest.

\section{ACKNOWLEDGMENTS}

A.H. appreciates National Science Centre, Poland, for financial support from grant No. 2016/23/B/ST5/00615.

\section{REFERENCES}

(1) Weckhuysen, B. M.; Keller, D. E. Chemistry, spectroscopy and the role of supported vanadium oxides in heterogeneous catalysis. Catal. Today 2003, 78, 25-46.

(2) Fievez, T.; De Proft, F.; Geerlings, P.; Weckhuysen, B. M.; Havenith, R. W. A. Conceptual chemistry approach towards the support effect in supported vanadium oxides: Valence bond calculations on the ionicity of vanadium catalysts. Catal. Today 2011, 177, 3-11.

(3) Rozanska, X.; Kondratenko, E. V.; Sauer, J. Oxidative dehydrogenation of propane: Differences between $\mathrm{N}_{2} \mathrm{O}$ and $\mathrm{O}_{2}$ in the reoxidation of reduced vanadia sites and consequences for selectivity. J. Catal. 2008, 256, 84-94.

(4) Ferreira, M. L.; Volpe, M. On the nature of highly dispersed vanadium oxide catalysts: effect of the support on the structure of $\mathrm{VO}_{\mathrm{x}}$ species. J. Mol. Catal. A: Chem. 2000, 164, 281-290.

(5) Zhao, C.; Wachs, I. E. Selective oxidation of propylene over model supported $\mathrm{V}_{2} \mathrm{O}_{5}$ catalysts: Influence of surface vanadia coverage and oxide support. J. Catal. 2008, 257, 181-189.

(6) Held, A.; Kowalska-Kuś, J.; Nowińska, K. Epoxidation of propene on vanadium species supported on silica supports of different structure. Catal. Commun. 2012, 17, 108-113.

(7) Held, A.; Kowalska-Kuś, J.; Łapiński, A.; Nowińska, K. Vanadium species supported on inorganic oxides as catalysts for propene epoxidation in the presence of $\mathrm{N}_{2} \mathrm{O}$ as an oxidant. J. Catal. 2013, 306, $1-10$.

(8) Dzwigaj, S.; Massiani, P.; Davidson, A.; Che, M. Role of silanol groups in the incorporation of $\mathrm{V}$ in $\beta$ zeolite. J. Mol. Catal. A: Chem. 2000, 155, 169-182.

(9) Dzwigaj, S.; Matsuoka, M.; Anpo, M.; Che, M. A comparative study of $\mathrm{V}$ species in $\mathrm{B}$ zeolite by photoluminescence, diffuse reflectance UV-Visible and ${ }^{51} \mathrm{~V}$ NMR spectroscopies. Catal. Lett. 2001, 72, 211-214.

(10) Solsona, B.; Blasco, T.; López Nieto, J. M.; Pena, M. L.; Rey, F.; Vidal-Moya, A. Vanadium oxide supported on mesoporous MCM-41 as selective catalysts in the oxidative dehydrogenation of alkanes. $J$. Catal. 2001, 203, 443-452.

(11) Bulánek, R.; Čičmanec, P.; Sheng-Yang, H.; Knotek, P.; Čapek, L.; Setnička, M. Effect of preparation method on nature and distribution of vanadium species in vanadium-based hexagonal mesoporous silica catalysts: Impact on catalytic behavior in propane ODH. Appl. Catal., A 2012, 415-416, 29-39.

(12) Florea, M.; Silvy, R. P.; Grange, P. Vanadium aluminium oxynitride catalysts for propane ammoxidation reaction: Effect of the $\mathrm{V} / \mathrm{Al}$ ratio on the structure and catalytic behaviour. Appl. Catal., A 2005, 286, 1-10.

(13) Baes, C. F., Jr.; Mesmer, R. E. The Hydrolysis of Cations; Krieger Publishing Company: Malabar, 1986; p 210.

(14) Spałek, T.; Pietrzyk, P.; Sojka, Z. Application of the genetic algorithm joint with the Powell method to nonlinear least-squares fitting of powder EPR spectra. J. Chem. Inf. Model. 2005, 45, 18-29.

(15) Held, A.; Kowalska-Kuś, J.; Nowińska, K.; Góra-Marek, K. Potassium-modified silica-supported vanadium oxide catalysts applied for propene epoxidation. J. Catal. 2017, 347, 21-35.

(16) Lu, J.; Zhang, X.; Bravo-Suárez, J. J.; Bando, K. K.; Fujitani, T.; Oyama, S. T. Direct propylene epoxidation over barium-promoted $\mathrm{Au} / \mathrm{Ti}$-TUD catalysts with $\mathrm{H}_{2}$ and $\mathrm{O}_{2}$ : Effect of Au particle size. J. Catal. 2007, 250, 350-359.

(17) Ivanova, E.; Hadjiivanov, K.; Dzwigaj, S.; Che, M. FT-IR study of $\mathrm{CO}$ and NO adsorption on a VSiBEA zeolite. Microporous Mesoporous Mater. 2006, 89, 69-77.
(18) Dzwigaj, S.; Peltre, M. J.; Massiani, P.; Davidson, A.; Che, M.; Sen, T.; Sivasanker, S.; et al. Incorporation of vanadium species in a dealuminated $\beta$ zeolite. Chem. Commun. 1998, 87-88.

(19) Hajjar, R.; Millot, Y.; Man, P. P.; Che, M.; Dzwigaj, S. Two kinds of framework $\mathrm{Al}$ sites studied in BEA zeolite by $\mathrm{X}$-ray diffraction, Fourier Transform Infrared Spectroscopy, NMR techniques, and V probe. J. Phys. Chem. C 2008, 112, 20167-20175.

(20) Tielens, F.; Calatayud, M.; Dzwigaj, S.; Che, M. What do vanadium framework sites look like in redox model silicate zeolites? Microporous Mesoporous Mater. 2009, 119, 137-143.

(21) Emeis, C. A. Determination of integrated molar extinction coefficients for infrared absorption bands of pyridine adsorbed on solid acid catalysts. J. Catal. 1993, 141, 347-354.

(22) Trejda, M.; Ziolek, M.; Millot, Y.; Chalupka, K.; Che, M.; Dzwigaj, S. Methanol oxidation on VSiBEA zeolites: Influence of V content on the catalytic properties. J. Catal. 2011, 281, 169-176.

(23) Centi, G.; Perathoner, S.; Trifiro, F.; Aboukais, A.; Aïssi, C. F.; Guelton, M. Physicochemical characterization of V-silicalite. J. Phys. Chem. 1992, 96, 2617-2629.

(24) Baran, R.; Millot, Y.; Onfroy, T.; Averseng, F.; Krafft, J.-M.; Dzwigaj, S. Influence of the preparation procedure on the nature and environment of vanadium in VSiBEA zeolite: XRD, DR UV-vis, NMR, EPR and TPR studies. Microporous Mesoporous Mater. 2012, $161,179-186$.

(25) Siegel, I. Paramagnetic Resonance of Vanadium in Amorphous and Polycrystalline $\mathrm{GeO}_{2}$. Phys. Rev. 1964, 134, A193.

(26) Trombetta, M.; Busca, G.; Storaro, L.; Lenarda, M.; Casagrande, M.; Zambon, A. Surface acidity modifications induced by thermal treatments and acid leaching on microcrystalline H-BEA zeolite. A FTIR, XRD and MAS-NMR study. Phys. Chem. Chem. Phys. 2000, 2, 3529-3537.

(27) Boix, A.; Miro, E. E.; Lombardo, E. A.; Bañares, M. A.; Mariscal, R.; Fierro, J. L. G. The nature of cobalt species in Co and PtCoZSM5 used for the SCR of $\mathrm{NO}_{x}$ with $\mathrm{CH}_{4}$. J. Catal. 2003, 217, 186-194.

(28) Duma, V.; Hönicke, D. Gas phase epoxidation of propene by nitrous oxide over silica-supported iron oxide catalysts. J. Catal. 2000, 191, 93-104.

(29) Lu, J.; Bravo-Suárez, J. J.; Haruta, M.; Oyama, S. T. Direct propylene epoxidation over modified $\mathrm{Ag} / \mathrm{CaCO}_{3}$ catalysts. Appl. Catal., A 2006, 302, 283-295.

(30) Ananieva, E.; Reitzmann, A. Direct gas-phase epoxidation of propene with nitrous oxide over modified silica supported $\mathrm{FeO}_{\mathrm{x}}$ catalysts. Chem. Eng. Sci. 2004, 59, 5509-5517.

(31) Held, A.; Kowalska-Kuś, J.; Nowińska, K. Propane-to-propene oxide oxidation on silica-supported vanadium catalysts with $\mathrm{N}_{2} \mathrm{O}$ as an oxidant. J. Catal. 2016, 336, 23-32.

(32) Coxon, J. M.; Maclagan, R. G. A. R.; Rauk, A.; Thorpe, A. J.; Whalen, D. Rearrangement of protonated propene oxide to protonated propanal. J. Am. Chem. Soc. 1997, 119, 4712-4718.

(33) Fási, A.; Gömöry, Á.; Pálinkó, I.; Kiricsi, I. Isomerization and dimerization reactions of methyloxirane over various types of zeolite and zeotype. J. Catal. 2001, 200, 340-344.

(34) Li, M.; Shen, J. Microcalorimetric adsorption characterizations of supported vanadia catalysts for the selective oxidation of propylene to acetone. J. Catal. 2002, 205, 248-258.

(35) Gao, X.; Wachs, I. E. Investigation of surface structures of supported vanadium oxide catalysts by UV-vis-NIR diffuse reflectance spectroscopy. J. Phys. Chem. B 2000, 104, 1261-1268.

(36) Chen, K.; Bell, A. T.; Iglesia, E. Kinetics and mechanism of oxidative dehydrogenation of propane on vanadium, molybdenum, and tungsten Oxides. J. Phys. Chem. B 2000, 104, 1292-1299. 